\title{
Review
}

Neuro[mmunoModulation

\section{Immunological Dysfunction in Autism Spectrum Disorder: A Potential Target for Therapy}

\author{
Josemar Marchezan ${ }^{a, c, d}$ Eduardo Geyer Arrussul Winkler dos Santos ${ }^{a, c, e}$ \\ Iohanna Deckmann ${ }^{\mathrm{a}-\mathrm{c}, \mathrm{f}}$ Rudimar dos Santos Riesgo ${ }^{\mathrm{a}, \mathrm{c}, \mathrm{d}, \mathrm{g}}$
}

aTranslational Research Group in Autism Spectrum Disorders GETTEA, Universidade Federal do Rio Grande do Sul, Porto Alegre, Brazil; ' Neuroglial Plasticity Group, Department of Biochemistry, Universidade Federal do Rio Grande do Sul, Porto Alegre, Brazil; ' National Institute of Science and Technology on Neuroimmunomodulation (INCT-NIM), Porto Alegre, Brazil; ' d Postgraduate Program in Child and Adolescent Health, School of Medicine, Universidade Federal do Rio Grande do Sul, Porto Alegre, Brazil; e School of Medicine, Universidade Federal do Rio Grande do Sul, Porto Alegre, Brazil; f Postgraduate Program in Biological Sciences: Biochemistry, Biochemistry Department, Universidade Federal do Rio Grande do Sul, Porto Alegre, Brazil; ${ }^{9}$ Child Neurology Unit, Department of Pediatrics, Hospital de Clínicas de Porto Alegre, Porto Alegre, Brazil

\section{Keywords}

Autism spectrum disorder · Autism · Immune system · Immune therapy · Neuroimmune alterations

\begin{abstract}
Autism spectrum disorder (ASD) is a complex neurodevelopmental disorder with an unknown etiology and currently few effective therapies. Immune system alterations have being demonstrated in ASD, both in humans and via animal models; immune imbalance thus arises as a possible pathway for drug intervention. In this review, the studies were classified into 2 major groups: (1) clinical research whose authors classify therapies with primary anti-inflammatory and immunomodulatory actions, making use of: sulforaphane, celecoxib, lenalidomide, pentoxifylline, spironolactone, flavonoid luteolin, corticosteroids, oral immunoglobulin, intravenous immunoglobulin, cell therapy, dialyzable lymphocyte extracts, minocycline, and pioglitazone; and (2) other ASD ther-
\end{abstract}

apies already used or currently under study whose initial characteristics were neither anti-inflammatory nor immunomodulatory initially, but displayed a capacity for immunomodulation throughout the treatment: risperidone, vitamin D, omega-3, Ginkgo biloba, L-carnosine, N-acetylcysteine, and microbiome restoration. These studies used various data acquisition methodologies. Questions arose such the need for randomized and placebo-controlled studies with greater numbers of participants as well as the use of biomarkers to refine the treatment of autistic subjects.

(c) 2018 S. Karger AG, Basel

\section{Introduction}

Autism spectrum disorder (ASD) is a developmental disorder and its core symptoms are (1) deficits in social interaction, communication, and language, and (2) repetitive and stereotypical behaviors and/or a restricted rep-

\section{KARGER}

(c) 2018 S. Karger AG, Basel

E-Mail karger@karger.com

www.karger.com/nim
Josemar Marchezan, MD, MsC

Child Neurology Unit, Department of Pediatrics

Hospital de Clínicas de Porto Alegre

Ramiro Barcelos, 2350, Porto Alegre, RS 90035-903 (Brazil)

E-Mail j.marchezan@ @otmail.com 
ertoire of interests [1]. The diagnosis of autism (used here as synonymous with ASD throughout the text) has increased dramatically in the past decades [2,3]. In 2018, the Centers for Disease Control and Prevention (CDC) has estimated the prevalence of ASD to be 16.8/1,000 (i.e., $1 / 59$ ) in children 8 years of age, affecting 26.6/1,000 boys and 6.6/1,000 girls (i.e., a prevalence ratio of 4:1) [4]. This represents an increase of approximately $150 \%$ between 2000 and 2014 [4], making the disorder a public health problem [5, 6]. Studies in Asia, Europe, and North America report an average prevalence of ASD of around 1\% [3].

Despite the increase in the number of cases, the treatments available today only partially improve some, but do not completely reverse all, of the symptoms of ASD [7-9]. Only 2 drugs, risperidone and aripiprazole, have been approved by the US FDA for the treatment of disruptive symptoms in ASD patients [8,10-14]. In addition, factors such as (1) the condition of the individual, with many facets of daily functioning affected [15], (2) the substantial direct and indirect economic effects of treatments, and (3) how a subject's whole family suffers, reinforce the need for a continued search for effective interventions [16-20].

ASD is a complex neurodevelopmental disorder [3], and although a number of definitions and improvements have been made, its etiology remain unclear $[2,3,21]$. However, there is consensus in the autism research community that both genetic and environmental factors contribute to the symptoms, leaving no doubt of the multifactorial nature of ASD [2, 3, 21-23].

Immunological dysfunction has been a recognized feature in ASD for several decades and has been highlighted in recent revisions [2, 3, 8, 15, 21-26]. In 1976, a study found that 5 of 13 autistic children had undetectable antibody titers despite previous vaccination against Rubella while every control subject had detectable titers, making the first suggestion of a link between the immune system and ASD [26, 27]. Over the past few decades, studies on animal models and humans have shown evidence of alterations in central and peripheral immune system functioning in ASD, including stimulation of immune cells, generation of autoantibodies, cytokine/chemokine imbalance, and increased permeability of the blood-brain barrier $[2,3,8,15,21-26]$. Interestingly, many studies have also demonstrated a correlation between ASD status and cytokine levels and secretion [28-46], levels of immunoglobulins (IgM and IgG) [47], B lymphocyte antigen D8/17 expression [48], serum antineuronal antibodies [49-51], anti-ganglioside M1 antibodies [52], and maternal antibody status $[51,53]$. These data support the hypothesis that there is a subgroup of ASD individuals that has some form of immune system dysregulation, and that, at least in part, this dysregulation may contribute to the autistic phenotype $[2,3,8,15,21-26]$.

Many researchers suggest the possibility that immune dysfunction in ASD may be a viable pathway for drug intervention, so that a subgroup of ASD individuals could benefit from immune-based therapies [2, 3, 8, 21-24, 26, 54-56]. This review aims to describe the drugs that act on the immune system that have been studied in patients with autism.

\section{Methods}

The studies in this review were obtained from a comprehensive search of PubMed using the terms and keywords "autism," "autistic," "autistic spectrum disorder," "ASD," "Rett," "Asperger," "Pervasive Developmental Disorder," and "PDD" associated with the terms "treatment," "inflammation", "immunological drugs," "immune," "inflammation," "inflammatory," "anti-inflammatory," "immunomodulation," "immunology," "immunological," "neuroinflammation," "neuroinflammatory," "antibody," "antibodies," "immunoglobulin," "lymphocyte," "glial activation," "cytokine," "immunomodulatory," "BDNF" "sulforaphane," "pregnenolone," "celecoxib," "immunoglobulin," "ACTH," "lenalidomide," "pentoxifylline," "pioglitazone," "spironolactone," "corticosteroids," "probiotics," "luteolin," "transplant," "stem cells," "cell therapy," "autologous," "vitamin D," "risperidone," "naloxone," "minocycline," and "lymphocyte extract." The search included articles in English, Spanish, and Portuguese. Only studies conducted on humans were included.

\section{Findings Relating Immunological Dysfunction in ASD and Potential Therapies}

The inclusion of articles in this review was based on the classification criteria of the original articles which considered anti-inflammatory or immunomodulatory mechanisms of action in ASD therapies: (1) clinical research whose authors classified drugs with primary antiinflammatory and immunomodulatory actions: sulforaphane, celecoxib, lenalidomide, pentoxifylline (PTX), spironolactone, flavonoid luteolin, corticosteroids, oral immunoglobulin, intravenous immunoglobulin (IVIG), cell therapy, dialyzable lymphocyte extracts, minocycline, and pioglitazone (Table 1) (the side effects of these thera- 

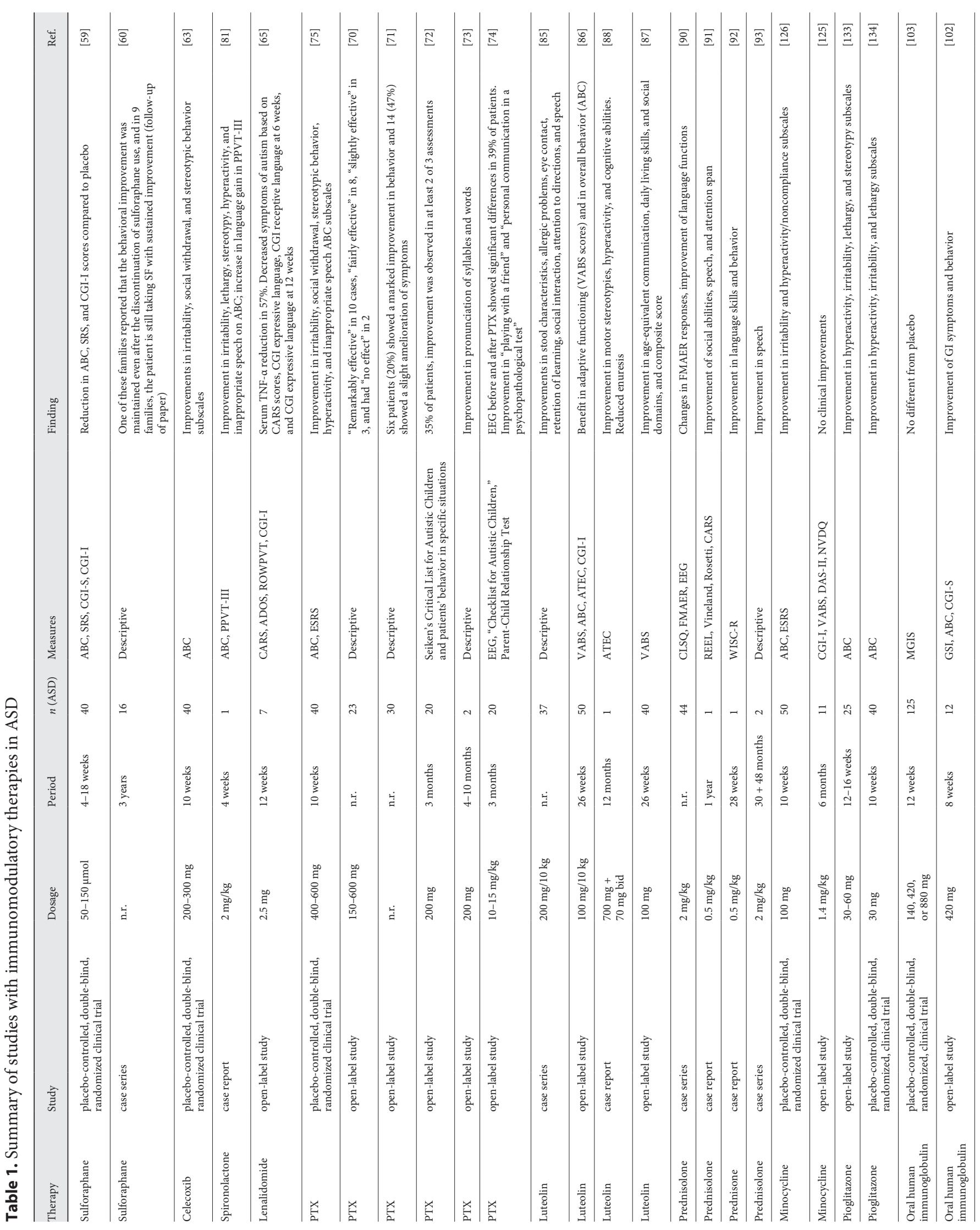


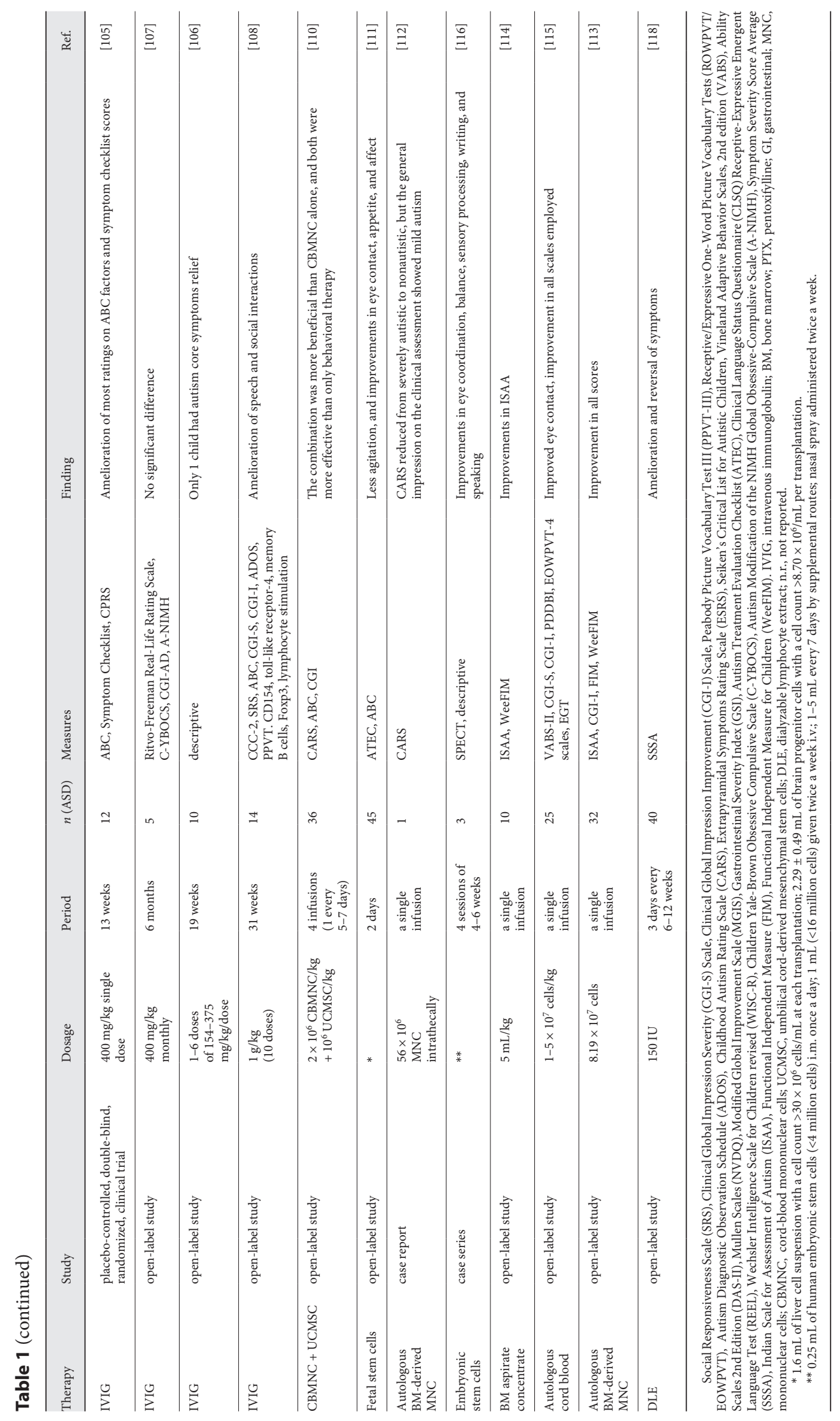


Table 2. Adverse events

\begin{tabular}{|c|c|c|}
\hline Therapy & Side effects & Ref. \\
\hline Sulforaphane & Greater weight gain and a possible association with seizures & {$[59]$} \\
\hline Lenalidomide & Rash and a transient drop of absolute neutrophil count & {$[65]$} \\
\hline Pentoxifylline & Nausea, vomiting, low blood pressure, and headache & {$[70]$} \\
\hline Pentoxifylline & Limited to the gastrointestinal tract & {$[72]$} \\
\hline Luteolin & Increased irritability & {$[86]$} \\
\hline Prednisolone & $\begin{array}{l}\text { Cushing syndrome, irritability. Gastrointestinal bleeding and hypercalcemia } \\
\text { (both self-limited) }\end{array}$ & {$[90]$} \\
\hline Minocycline & $\begin{array}{l}\text { Gastrointestinal and upper respiratory symptoms, pica, hematuria, weight gain, } \\
\text { hyperactivity, urinary tract infection, otitis media, epistaxis, teeth staining, } \\
\text { increased aggression, head-banging, sensitivity to light, appetite loss, and } \\
\text { ritualistic behavior }\end{array}$ & {$[125]$} \\
\hline Pioglitazone & $\begin{array}{l}\text { Transitory and self-limited elevations in white blood count, glucose levels, and } \\
\text { liver enzymes }\end{array}$ & [133] \\
\hline Oral human immunoglobulin & Skin and subcutaneous tissue disorders & {$[103]$} \\
\hline Oral human immunoglobulin & Vomiting, skin rash & {$[103]$} \\
\hline Intravenous immunoglobulin & Mild headaches and infusion-site reactions & {$[108]$} \\
\hline $\begin{array}{l}\text { Mononuclear cells and } \\
\text { mesenchymal stem cells }\end{array}$ & Self-limited low-grade fever & {$[110]$} \\
\hline Autologous cord blood & Allergic reaction, skin changes, agitation, and childhood infections & {$[115]$} \\
\hline $\begin{array}{l}\text { Autologous bone marrow-derived } \\
\text { mononuclear cells }\end{array}$ & Headache, nausea and vomiting, pain at the procedure site, and seizures & {$[113]$} \\
\hline
\end{tabular}

pies are described in Table 2); and (2) other therapies for ASD already used or currently under study whose initial characteristics were neither anti-inflammatory nor immunomodulatory, but displayed a potential immunomodulation capacity throughout the treatment: risperidone, vitamin D, omega-3, Ginkgo biloba, L-carnosine, $\mathrm{N}$-acetylcysteine (NAC), and microbiome restoration.

\section{Sulforaphane}

Sulforaphane is an isothiocyanate derived from various Brassica vegetables (especially broccoli) [57] with anticancer effects [58] and a potential protective effect in neurodegenerative diseases [57]. This therapeutic effect is based on the upregulation of gene transcription related to cell mechanisms of protection against oxidative stress, inflammation, DNA-damaging electrophiles, and radiation [59].

A placebo-controlled, double-blind, randomized trial evaluated the effect of sulforaphane for up to 18 weeks in 40 male patients with ASD (26 sulforaphane-treated and
14 placebo-treated), at a dose of $50-150 \mu \mathrm{M}$ per day. In the treatment group, the Aberrant Behavior Checklist (ABC) mean score differed at 4,10 , and 18 weeks from baseline, and at 18 weeks there was a decrease of $34 \%$ in the ABC score and $17 \%$ in the Social Responsiveness Scale (SRS) score. Significant improvement was observed in the ABC subscales: irritability, lethargy, stereotypy, and hyperactivity, and in the SRS subscales: awareness, communication, motivation, and mannerisms. After stopping sulforaphane treatment, both the ABC and SRS subscores tended to return to the baseline score. On the subscale analysis of Clinical Global Impression Improvement (CGI-I) scores at the 18th week, social interaction, aberrant behavior and verbal communication were much improved in sulforaphane users compared to in placebotreated subjects. Sulforaphane treatment was safe and well-tolerated, but a higher weight gain over the period was observed compared with placebo. Two participants had single, unprovoked seizures; their relation to sulforaphane use could not be ruled out [59]. After 2 years, the 
researchers reassessed the patients' progress. Among 16 patients, 1 family reported a maintained behavioral improvement even after the discontinuation of sulforaphane use, and in 9 families the patient was still taking sulforaphane with improvement [60].

\section{Celecoxib}

Celecoxib is a nonsteroidal anti-inflammatory drug that reduces the cytokine-induced activation of COX-2 and inhibits the NF- $\kappa B$ pathway $[61,62]$. Celecoxib was used as associated therapy in the ASD treatment in a randomized, double-blind, placebo-controlled study. Forty children were randomly allocated to a celecoxib + risperidone or placebo + risperidone group for 10 weeks. The dose was $200 \mathrm{mg}$ /day for patients weighing $<30 \mathrm{~kg}$ and $300 \mathrm{mg} /$ day for patients $>30 \mathrm{~kg}$. At week 10, the risperidone + celecoxib group demonstrated significant improvements in irritability, social withdrawal, and stereotypic behavior evaluated as ABC subscales when compared to the risperidone + placebo group. No significant difference was observed between the 2 groups regarding extrapyramidal symptoms or other side effects [63].

\section{Lenalidomide}

Lenalidomide is an analog of thalidomide used in myelodysplastic syndromes and more recently for therapy after autologous hematopoietic stem cell (HSC) transplantation [64]. It has lower toxicity than thalidomide and displays a greater modulatory potency of tumor necrosis factor (TNF)- $\alpha$ and other immunomodulatory cytokines. Lenalidomide arises as a possible treatment in patients with elevated TNF- $\alpha$ in the serum or cerebrospinal fluid (CSF), interleukin (IL)-1, IL-6, or methyl CpGbinding protein (MeCP)-1 [65].

An open-label study was conducted on 7 autistic male subjects aged 6-12 years with elevated TNF- $\alpha$ in their CSF $(>50 \mathrm{pg} / \mathrm{mL})$ to evaluate the effects of daily treatment with lenalidomide $(2.5 \mathrm{mg})$ for 12 weeks, with evaluation at weeks 6 and 12. At the end of the study, serum and CSF TNF- $\alpha$ were reduced by $57 \%$, but this reduction did not reach statistical significance. Six children who completed the 6-week follow-up showed decreased symptoms of autism based on the Childhood Autism Rating Scale (CARS), and an improvement in CGI expressive and receptive language scores but not in One-Word Receptive Language Testing (ROWPVT) scores. At 12 weeks of follow-up, CGI expressive language remained improved from baseline, but CGI receptive language and CARS showed similar values. Differences in social skill were not significant compared to baseline. Three patients were withdrawn

Immunological Therapy in ASD from the study because of reactions to the drug which then disappeared [65].

\section{Pentoxifylline}

PTX is a xanthine analog known as a phosphodiesterase inhibitor [66] with modulatory effects on cytokines such TNF- $\alpha$, IL-10, and interferon (IFN)- $\gamma$ [67], and it was proposed as a potential treatment for autistic patients in the 1970s and 1980s. Gupta et al. [68, 69] described 5 case series in a 1996 review:

(1) Twenty-three ASD children were treated with PTX (150-600 mg/day orally). Within 1 month of therapy, the drug was considered "remarkably effective" in 10 cases, "fairly effective" in 8 , "slightly effective" in 3 , and had "no effect" in 2. Side effects in a small number of patients included nausea, vomiting, low blood pressure, and headache [70].

(2) Thirty ASD children were evaluable after receiving PTX (with no dosage or duration of treatment specified). Six patients (20\%) showed a marked improvement in behavior and $14(47 \%)$ had a slight amelioration of symptoms [71].

(3) Shimoide [72] treated 20 male ASD patients with PTX (most of them received $200 \mathrm{mg} /$ day) for 3 months. They were evaluated by means of a mental development scale for young children, Seiken's Critical List for Autistic Children and regarding their behavior in specific situations. In 35\%, improvement was observed in at least 2 of 3 assessments. Side effects were limited to the gastrointestinal (GI) tract.

(4) The results of treatment of 18 psychotic and 2 autistic (a boy of 5 years and a girl of 7 years) children with PTX (mostly $200 \mathrm{mg} /$ day) for 4-10 months revealed "highly positive" improvements in behavior ( 12 children) and language (14 children). In the autistic children, an improvement in the pronunciation of syllables and words was noted. Side effects included excitation (3 patients) and disturbed sleep (2 patients), which disappeared without discontinuing PTX [73].

(5) PTX was administered to 20 children with early infantile autism at a dose of $10-15 \mathrm{mg} / \mathrm{kg} / \mathrm{day}$ split into 2 doses, for 3 months, with the aim of evaluating electroencephalogram (EEG) activity changes via autoregressive analysis software (ARASIS). EEG before and after PTX administration showed significant differences in $7 / 18$ (39\%) patients. "Playing with a friend" and "personal communication in a psychopathological test" were improved [74].

A placebo-controlled, double-blind trial randomized 40 patients to either PTX + risperidone or placebo + ris- 
peridone for 10 weeks, with evaluation at baseline and at weeks $2,4,6,8$, and 10 . The dose of PTX was $400 \mathrm{mg} /$ day for children weighing 10-40 kg and $600 \mathrm{mg}$ for children $>40 \mathrm{~kg}$. The PTX + risperidone group demonstrated significantly greater improvement on 5 ABC subscales: irritability, social withdrawal, stereotypic behavior, hyperactivity, and inappropriate speech. No differences in extrapyramidal symptoms or side effects were observed [75].

\section{Spironolactone}

Spironolactone is a synthetic 17-lactone steroid, belonging to the "potassium-sparing diuretics" class of drugs and is known as a competitive aldosterone antagonist [76] with potent anti-inflammatory, immunologic, and hormone-modifying properties [77-80]. Currently, this drug has been used for acne, hirsutism, and precocious puberty, demonstrating safety and tolerability.

Bradstreet et al. [81] reported a case of a 12-year-old autistic boy with immune dysregulation, food allergies, and elevated testosterone levels. He demonstrated a significant reduction in both the severity and frequency of several aberrant symptoms during 4 weeks of daily spironolactone administration $(2 \mathrm{mg} / \mathrm{kg})$. Comparing the $\mathrm{ABC}$ scores before and after the spironolactone implementation, there was a $79 \%$ improvement in irritability, an $83 \%$ decrease in lethargy, a $60 \%$ reduction in stereotypy, a $72 \%$ reduction in hyperactivity, and a $67 \%$ decrease in inappropriate speech. There was a receptive language gain of 21 months, indicating an increase in vocabulary $>1 \mathrm{SD}$ at either age level as evaluated in the Peabody Picture Vocabulary Test III (PPVT-III).

\section{Flavonoid Luteolin}

Luteolin is a natural flavonoid with antioxidant and anti-inflammatory properties and is found in a myriad of plants [82]. Dietary sources of flavonoid luteolin include carrots, peppers, oregano, and olive oil [83]. In humans, luteolin has been demonstrated to inhibit the secretion of proinflammatory mediators from mast cells [84].

In 1 study, 37 ASD children ( 29 boys and 8 girls, age range 4-14 years) received a dietary flavonoid formulation (NeuroProteka) containing mainly luteolin (100 $\mathrm{mg}$ ): $75.67 \%$ of the subjects had improvements in the color, shape, or smell of their stools; $51.35 \%$ got fewer "allergic problems"; $40.54 \%$ started to have better eye contact; $40.54 \%$ showed more retention of learned behavior; $37.83 \%$ had more social interaction; $32.43 \%$ improved their attention to directions; and $10.81 \%$ got better at speaking words or sentences. This study lacked any specific psychometric instrument or an independent assess- ment by an external evaluator. The authors did not clarify treatment or follow-up duration [85].

Another open-label trial assessed the same dietary supplement (100 mg of luteolin) in 42 boys and 8 girls aged 4-10 years for a 26 -week period. Primary outcomes were age-equivalent scores in the 3 Vineland Adaptive Behavior Scale (VABS) domains: communication, daily living skills, and social. Secondary outcomes were ABC, Autism Treatment Evaluation Checklist (ATEC), and CGI-I scores. There was a significant improvement in adaptive functioning (for all 3 above domains) measured by VABS age-equivalent scores, as well as in overall behavior indicated by the reduction in $\mathrm{ABC}$ subscale scores. There was a transient period (1-8 weeks) of increased irritability in 27 of the 50 participants [86].

In a 2015 work, 40 patients diagnosed with ASD received a luteolin-containing dietary formulation for 26 weeks, reducing autism symptoms and serum levels of TNF and IL-6. At baseline, IL-6 levels were elevated (with no statistical significance) and TNF serum levels were significantly higher in ASD patients. Interestingly, there were 2 subgroups of ASD subjects in this study, i.e., with low and high serum IL- 6 and TNF levels. The latter group $(n=10)$ had a significant improvement in the VABS ageequivalent scores for all domains and in VABS composite score. At 26 weeks, patients had improved in several behavioral domains, equivalent to 9.73 months in the communication domain, 8.09 months in the social domain, and 6.64 months in the daily living skills domain [87].

In a recent study, an association of palmitoylethanolamide + luteolin $(700+70 \mathrm{mg}$ twice a day for 1 year) was given to a 10 -year-old male autistic patient. The evaluation with the ATEC questionnaire showed a decrease in scores, showing improvement in behavioral results. The treatment reduced stereotypic behaviors, significantly improved the cognitive domain (observed by parents and teachers) and, curiously, decreased enuresis of the subject after 14 months of treatment [88].

\section{Corticosteroids}

Corticosteroids are anti-inflammatory drugs that inhibit the secretion of proinflammatory mediators, alter $\mathrm{T}$ cell activity, and may also interfere with microglial activation [89]. One retrospective study with oral prednisone (2 $\mathrm{mg} / \mathrm{kg} /$ day for 9-12 months) treatment assessed ASD patients by means of the Clinical Language Status Questionnaire (CLSQ), Frequency Modulated Auditory Evoked Response (FMAER) testing, and EEG. For the treated group (20 participants), 9/14 electrode measurements of an FMAER $4-\mathrm{Hz}$ response had a statistically significant 
modification, but more importantly, this was found at the left posterior-inferior temporal electrode (TP9). On the other hand, no difference was seen in the control group (24 nontreated subjects). EEGs of the treated and control groups showed no differences. The steroid-treated group also had a significant increase in the mean CLSQ scores after the therapy [90].

Shenoy et al. [91] reported a response to steroid therapy in a case of ASD secondary to an autoimmune syndrome. The patient was treated with different regimens of oral prednisolone, with an average dose of $0.5 \mathrm{mg} / \mathrm{kg}$ daily. The ASD symptoms improved progressively during the course of 1 year after the corticosteroid therapy. In a similar study, a child with language and behavior regression at 22 months of age (diagnosed later with pervasive developmental disorder) received prednisone $(2 \mathrm{mg} / \mathrm{kg} /$ day) for 28 weeks. The results observed were speech amelioration, better responsiveness to verbal communication, improved social relationships, and fewer motor stereotypies [92].

Mordekar et al. [93] reported on 2 patients diagnosed with childhood disintegrative disorder that were also treated with corticosteroids, showing a similar clinical improvement. On prednisone treatment ( $2 \mathrm{mg} / \mathrm{kg}$ daily), the first patient showed a recovery of speech at day 11 of therapy. The second subject, on the same dose for 1 week, had progressive speech improvement over the course of 48 months.

In the 1990s, several studies were conducted with ORG 2766 , a synthetic analog of the adrenocorticotrophic hormone (4-9). However, ORG 2766 has no substantial steroidogenic activity and may exert its effects via an interaction with endogenous opioid systems [94-98]. Another open-label study using the neurosteroid pregnenolone found improvements in ASD patients; considering that this drug did not alter cortisol levels, the authors suggested that pregnenolone would act by modulating $\mathrm{GABA}_{\mathrm{A}}$ receptors, altering the ratio of excitation/inhibition in key neural systems $[99,100]$.

\section{Oral Immunoglobulin}

Oral immunoglobulin, constituted predominantly of IgG, is a medication prepared from immunoglobulins obtained from human and bovine serum and bovine milk. Several studies demonstrate its survival to gastric exposure and a resistance to proteolytic digestion in the GI tract [101].

Schneider et al. [102] administered oral immunoglobulin in a pilot study with 12 male ASD subjects, considering the chronic GI disturbances in ASD due to an under- lying deficiency in mucosal immunity. By the fourthweek assessment, $50 \%$ of subjects had improvements in GI symptoms.

Similarly, Handen et al. [103] tested oral human immunoglobulin efficacy for GI symptoms in ASD. One hundred and twenty-five ASD children were treated with different doses of immunoglobulin $(140,420$, or $840 \mathrm{mg} /$ day) or placebo. The primary outcome was measurement by a Modified Global Improvement Scale (MGIS), which showed no significant changes between the groups.

\section{Intravenous Immunoglobulin}

IVIG is a treatment that contains a pool of several molecules of IgG from the human plasma ( $>95 \%$ unmodified $\operatorname{IgG})$ [104]. Although it is widely used, the mechanism of action of IVIG for the treatment of autoimmune disorders is still unclear [23].

A clinical trial with 12 male ASD children receiving a single dose of IVIG $(0.4 \mathrm{~g} / \mathrm{kg})$ or placebo evaluated the subjects after 6 or 13 weeks of therapy. There were significant improvements in irritability, hyperactivity, inadequate eye contact, and inappropriate speech scores on the $\mathrm{ABC}$, besides a better score for drowsiness. There were no side effects from the treatment [105].

In an open-label clinical trial, 5 children diagnosed with autism received monthly IVIG infusions at a dose of $400 \mathrm{mg} / \mathrm{kg}$ for 6 months. No improvements were noted and no side effects cited [106]. In another open-label trial, 10 ASD children with blood immunologic abnormality, such as an increased percentage of lymphocytes expressing the DR antigen, received 1-6 IVIG infusions (154$375 \mathrm{mg} / \mathrm{kg}$ ). In 5 cases, no improvement was perceived; in 4 cases, the parents noticed a mild amelioration of attention and hyperactivity but no differences in the core symptoms of autism. One 5-year-old who received infusions of $375 \mathrm{mg} / \mathrm{kg}$ experienced remarkable relief of autistic symptoms (e.g., started to speak for the first time). There were no adverse effects [107].

A recent pilot study investigated the efficacy and tolerability of IVIG as 10 infusions of $1 \mathrm{~g} / \mathrm{kg}$ every $21 \pm 7$ days in 14 autistic patients with an immunological imbalance (e.g., T or B cell dysfunction or recurrent infections). The amelioration of behavioral symptoms was measured by means of SRS, PPVT, Children's Communication Checklist 2 (CCC-2), ABC, and Autism Diagnostic Observation Scale (ADOS) scores. For the SRS, there was a significant improvement in overall score, autistic mannerisms, social cognition, and social motivation. On the CCC-2, advances in the speech and semantics domains were reported. The ABC scores did not change. On the other hand, the 
ADOS scores changed significantly regarding stereotyped behaviors and restricted interests, communication and social interaction, and reciprocal social interaction. In relation to immunological markers after treatment, there were alterations in TNF- $\alpha$ and IL- $1 \beta$ levels. Adverse events with IVIG included mild headaches and infusionsite reactions [108].

\section{Cell Therapy}

Conceptually, cellular therapy with HSC (cord-derived and bone marrow-derived) may help the inflammation balance through immune regulation [109].

An open trial studied 36 ASD patients treated with placebo, cord-blood mononuclear cells (CBMNC), or umbilical cord-derived mesenchymal stem cells (UCMSC) + CBMNC. The only adverse event reported during the follow-up period was a self-limited low-grade fever in 5 subjects in the combination treatment group. Similarly, no significant hepatic, renal, hematological, or metabolic abnormalities occurred after therapy. Both intervention groups showed significant improvement in CARS and total ABC scores at 24 weeks in comparison to baseline, with the combination group presenting better results than the CBMNC-only group. Statistically significant differences were also shown on CGI evaluation in the 2 treatment groups compared to controls at 24 weeks [110].

The efficacy and safety of fetal stem cell therapy was verified in 45 ASD subjects by ATEC and ABC evaluation, laboratory tests, and clinical examination. After 6 months of therapy, B cell counts decreased significantly, while CD3 and CD4 counts were increased after 12 months. A significant lowering of ATEC overall score was seen 12 months after therapy, and in total ABC scores after 6 and 12 months. No side effects were observed [111].

Initially, Sharma et al. [112] used autologous bone marrow mononuclear cells (BMMNC) intrathecally in a 14-year-old boy, noting symptomatic improvement, with a change in CARS from severely autistic to nonautistic and enhanced brain function on positron emission tomography-computed tomography (PET-CT).

Subsequently, an open-label proof-of-concept study used intrathecal BMMNC transplantation in association with occupational, speech, and psychological therapies in 32 ASD patients. There was a significant difference between the pre- and posttreatment CGI-I scores and in total Indian Scale for Assessment of Autism (ISAA) scores. All ISAA domains also showed significant decreases. The Functional Independence Measure (FIM) and FIM for Children (WeeFIM) scores showed no changes. PET-CT detected changes in glucose metabolism in the form of
FDG uptake in different cerebral regions. Seizures and minor adverse events, such as headache, nausea, vomiting, and pain related to the procedure were reported [113].

An open-label trial tested the effects of intrathecal administration of autologous bone marrow concentrate (BMAC) cell therapy in 10 subjects with autism. Mean ISAA score of the patients decreased (i.e., improved) by $8 \%$ in the first 3 months after BMAC injection, and further diminished by $6 \%$ from 3 to 6 months. Changes in WeeFIM score did not reach statistical significance. The patients showed no adverse reactions [114].

Another open-label clinical trial tested the safety and feasibility of administering an autologous cord-blood infusion to 25 ASD children. Significant improvements in behavior were found across a wide range of outcome measures: the VABS-II socialization domain, the CGI-I, the Pervasive Developmental Disorder Behavior Inventory (PDDBI), and the Expressive One-Word Picture Vocabulary Test 4 (EOWPVT). Most of the observed behavioral changes occurred during the first 6 months and were sustained between 6 and 12 months. A higher nonverbal IQ was associated with greater improvements. The EyeGaze Tracking showed a 20\% increase that the children would gaze at an actress' eyes. Mild adverse events were seen: allergic reactions to infusion, skin changes, agitation, and common childhood infections [115].

Lastly, a case series report described improvement in 3 children with autism after an infusion of human embryonic stem cells. Better communication, attention to gaze, and cognitive performance were observed, besides improvements in brain blood perfusion reflected in the PET-CT. No side effects were noted [116].

\section{Dialyzable Lymphocyte Extract}

Dialyzable lymphocyte extracts are complexes of lowmolecular-weight substances with the capacity for cellmediated immunity transfer, mainly due to the action of small peptides called "transfer factors" [117]. A study published in 1996 reported a follow-up of forty 5-yearolds with classical infantile autism and pseudoautism after three and a half years of dialyzable lymphocyte extract therapy. Twenty-eight patients showed improvement and 10 had remission of autistic symptoms. The article did not clarify the criteria used to define autism and pseudoautism [118].

\section{Minocycline}

Minocycline is a tetracycline antibiotic with potent anti-inflammatory and neuroprotective effects $[119,120]$. The exact immunomodulatory mechanism is not clear 
[121]. Minocycline decreases microglial activation, modulates pathways involved in neuroinflammation such as cytokine and chemokine networks (e.g., IL-6, IL-1 $\beta$, and TNF- $\alpha$ ), and reduces the activity of some metalloproteinases $[122,123]$. Clinical trials on patients with X-fragile syndrome have shown minocycline to be effective and safe in improving behavioral function [124, 125].

An open-label pilot trial was assessed with 11 ASD children treated with minocycline $(1.4 \mathrm{mg} / \mathrm{kg} /$ day $)+$ vi$\operatorname{tamin} \mathrm{B}_{6}(0.6 \mathrm{mg} / \mathrm{kg}$, to mitigate the potential for vestibular side effects) [126]. Clinical improvements were negligible, with the CGI Severity (CGI-S) score remaining stable and only 2 of 10 children demonstrating a "minimal improvement" on the CGI-I. VABS composite scores also showed little or no change. Adverse events reported by parents included GI and upper respiratory symptoms, hematuria, weight gain, pica, hyperactivity, urinary tract infection, otitis media, epistaxis, teeth staining, increased aggression, head-banging, sensitivity to lights, increased appetite, and ritualistic behavior. Laboratory assays demonstrated significant changes in the expression profile of brain-derived neurotrophic factor (BDNF) and hepatic growth factor (HGF) in the CSF and serum. Among the evaluated cytokines, only IL-8 was significantly reduced in the serum after treatment, with no changes in noted in the CSF. No significant pre- and posttreatment changes were seen in the profiles of plasma metalloproteinases.

Ghaleiha et al. [127] conducted a randomized, doubleblind, placebo-controlled trial with 50 ASD children that received minocycline (50 $\mathrm{mg}$ twice a day) + risperidone or placebo + risperidone for 10 weeks. The risperidone dose was $1 \mathrm{mg} /$ day for patients weighing $<20 \mathrm{~kg}$ and 2 $\mathrm{mg} /$ day for those weighing $\geq 20 \mathrm{~kg}$. A significantly greater score reduction in the irritability and hyperactivity/ noncompliance subscales of the $\mathrm{ABC}$ occurred in the minocycline group when compared with the placebo group at week 10 .

\section{Pioglitazone}

Pioglitazone belongs to the thiazolidinedione group and works via peroxisome proliferator-activated receptor (PPAR) $-\gamma$ [128]. This drug is frequently used as an antidiabetic agent and offers additional cardiovascular protection and lipid profile improvement [129]. PPAR ligands also have anti-inflammatory effects, downregulating or upregulating different components of the inflammatory response [130]. Thiazolidinediones have been tested in inflammatory disorders such as psoriasis [130] and asthma [131]. Pioglitazone effects on neuropsychiatric diseases have also been studied [132].
An open-label study evaluated the use of pioglitazone in 25 ASD subjects (age range 3-17 years) for 12-16 weeks with daily doses of $30 \mathrm{mg}$ (for the age range 3-5 years) or $60 \mathrm{mg}$ (age 6-17 years). Analysis revealed a significant decrease in $4 \mathrm{ABC}$ subscales, hyperactivity, irritability, lethargy, and stereotypy, after the administration of pioglitazone; $76 \%$ of the patients showed a $50 \%$ reduction in at least 1 subscale and there was a tendency for younger participants to benefit more from this drug. Transitory and self-limited elevations in white blood count, glucose level, and liver enzymes were noted [133].

Ghaleiha et al. [134] conducted a double-blind placebo-controlled trial of pioglitazone ( $30 \mathrm{mg} /$ day) as adjunctive treatment to risperidone during 10 weeks in 44 patients with ASD (aged 4-12 years). The pioglitazone group showed a significantly greater improvement in 3 $\mathrm{ABC}$ subscales, hyperactivity, irritability, and lethargy. The frequency of adverse effects was similar in the intervention and control groups.

\section{Risperidone}

Risperidone, an atypical antipsychotic, is widely used for the treatment of children with autism, and reduces the major behavioral disturbances such as irritability, aggression, and anxiety [135]. Studies suggest that risperidone has immunoregulatory effects, since it ameliorates several immunological changes (e.g., the expression of inflammatory cytokines, IL-1 $\beta$, and TNF- $\alpha$ ) [136-138]. Treatment has been associated with a decrease in serum levels of eotaxin and monocyte chemoattractant protein (MCP)-1. In addition, mean values of IL-5 were significantly higher in the group that responded to risperidone than in the nonresponders [139]. On the other hand, a previous study on ASD subjects found no changes in serum inflammatory markers after risperidone use despite clinical improvements [140]. Therefore, the association between immunological changes and clinical response is a possibility that should be further investigated.

\section{Supplements}

Vitamin D

Vitamin D deficiency has been implicated as a potential environmental factor linked to some autoimmune disorders and it plays an immunomodulatory role [141, 142]. Several studies have found lower levels of vitamin D in ASD children than in healthy controls [143-145]. Mostafa and Al-Ayadhi [141] reported that vitamin D deficiency could be involved in autoantibody production in patients with autism, and Cannell [146] suggested that vitamin $\mathrm{D}$ may reduce the severity of autism symptoms 
by its anti-inflammatory activity. A case report [147], along with open and controlled trials [142, 148], observed an ASD symptom scores reduction after vitamin $\mathrm{D}_{3}$ supplementation. However, recent placebo-controlled clinical trials have found divergent results following vitamin $\mathrm{D}_{3}$ supplementation for ASD $[149,150]$.

\section{Omega-3}

Omega-3 fatty acids have anti-inflammatory and immunomodulatory properties [151-153]. Supplementation with omega-3 decreases NF- $\kappa B$, IL-12, and IL-13 gene expression [154], and levels of macrophage inflammatory protein (MIP)-2, IL-6 [155], IL-17A [156], and TNF- $\alpha$ [155-158]. Despite being widely used as an alternative practice in children with ASD $[159,160]$, omega-3 supplementation cannot be recommended based on the evidence that is currently available [151, 160-164].

G. biloba (Ginkgoaceae) is an ancient Chinese tree with anti-inflammatory effects [165] and is one of the most globally consumed phytomedicines [166]. The effect of G. biloba on ASD has been studied in an open trial [167] and in a double-blind, placebo-controlled trial as an adjuvant therapy to risperidone [168], with 3 and 47 patients, respectively. It appeared to be safe and well-tolerated but did not demonstrate efficacy for autistic symptoms.

\section{L-Carnosine}

L-Carnosine is a dipeptide of the $\beta$-alanine and l-histidine amino acids. It is easily absorbed in the digestive tract, penetrates the blood-brain barrier, and has high bioavailability and membrane-stabilizing action [169]. Carnosine is a known antioxidant and neuroprotective agent $[170,171]$ and reduces inflammation and neurodegeneration by lowering TNF- $\alpha$ and nitric oxide synthesis [172]. The beneficial effects of L-carnosine on ASD symptoms could be attributed to immunomodulatory, antioxidant, glutamatergic, and NMDA- and GABA-modulatory activities [173].

Two randomized, placebo-controlled trials studied Lcarnosine in ASD children at a dose of $800 \mathrm{mg} /$ day. Chez et al. [174] evaluated 31 children for 8 weeks and found changes in multiple domains in the group that was given carnosine (receptive speech, social attention, and behavior). Hajizadeh-Zaker et al. [173] used L-carnosine + risperidone or placebo + risperidone for 10 weeks in 50 children. They found improvement in the hyperactivity/noncompliance $\mathrm{ABC}$ subscale in the L-carnosine group. A recent placebo-controlled clinical trial using $500 \mathrm{mg}$ of $\mathrm{L}$-carnosine for 2 months observed positive reductions in the scores for sleep duration, parasomnia, and total sleep disorders, but no behavioral changes in ASD children [175].

\section{$\mathrm{N}$-acetylcysteine}

NAC is an orally bioavailable prodrug of cysteine known for its use in acetaminophene overdose [176]. With anti-inflammatory properties through several cellular processes [177], NAC is a glutathione precursor and direct antioxidant, and hence inhibits upstream events leading to the activation of NF- $\kappa \mathrm{B}$ activation and other proinflammatory cytokines [177]. NAC also acts by inhibiting the inflammatory cytokines TNF- $\alpha$, IL- $1 \beta$, and IL-6, at the protein and microRNA levels, in lipopolysaccharide (LPS)-activated macrophage cell lines [178, 179].

Marler et al. [180] reported a case of a 4-year-old boy who showed improvement in refractory self-injury after NAC use, with the symptoms returning after stopping the medication and improving again after its restart. Other case report also describes improvements in severe aggression in adolescents after the use of NAC in association with quetiapine [181]. Ghanizadeh and Derakhshan [182] reported gains in social interaction, communication, hyperactivity, limited interests, and aggressive behaviors in an 8-year-old boy after NAC use. A randomized, placebo-controlled trial by Hardan et al. [183] demonstrated a significant reduction in irritability symptoms in 29 children with ASD. Additionally, 2 randomized, placebo-controlled trials of NAC in conjunction with risperidone for the treatment of irritability in patients with ASD (with 50 and 40 participants, respectively) showed a significant reduction in the $\mathrm{ABC}$ irritability subscale score in the NAC-treated groups [184, 185]. More recently, 2 other randomized, placebo-controlled trials found no benefit of NAC in children with autism $[186,187]$.

\section{Microbiome Restoration}

There is an elevated prevalence of GI disturbances in patients with ASD, such as fluctuations in bowel habits, chronic abdominal pain, and flatulence. Interestingly, untreated GI symptoms may worsen core behavioral symptoms. A proposed mechanism for these phenomena is a disruption in the "gut-brain axis," a communication between the enteric nervous system and the CNS. It has been suggested that the gut-brain axis conveys fundamental signals for neurodevelopment, and that its malfunctioning could be associated with the onset of neuropsychiatric disorders such as ASD [188].

Gut microbiota may be the agents of disruption in the gut-brain axis through indirect effects on the innate im- 
mune system. Changes in gut microbiome are thought to be related to the decreased integrity of the intestinal barrier, leading to the augmentation of toxin absorption e.g., LPS. LPS can act on hepatocytes, inducing the secretion of TNF- $\alpha$ which, in turn, stimulates the production of proinflammatory cytokines systemically, ultimately leading to brain microglial activation [189]. Hence, based on these statements, researchers suggest that strategies of restoring the physiological gut microbiome, such as probiotic supplementation and fecal microbiota transplant, might be able to improve GI and behavioral symptoms in ASD [190]. In the year 2000, Sandler et al. [191] described a series of autistic patients with regressive autistic traits and chronic diarrhea. Treatment with the antibiotic vancomycin was successful in providing short-term improvement in 8 of 10 children, but the gains did not endure [24].

A research paper by Kałużna-Czaplińska and Błaszczyk [192] presented the results of dietary supplementation with probiotics which decreased a fungal urinary biomarker (D-arabinitol) and improved ability of concentration and carrying out others in subjects diagnosed with ASD. Similarly, an open-label study published in 2017 tested the effects of fecal microbiota transfer on autistic subjects; the authors reported an improvement of GI symptoms of as high as $80 \%$ and a significant amelioration of behavioral disturbances [193]. Lastly, a clinical trial randomized infant participants to receive either placebo or a probiotic dietary supplement during the first 6 months of life. While 6 of 35 subjects in the control group developed either attention deficit and hyperactivity disorder or Asperger syndrome later in life, none of the probiotics group had this outcome [194].

\section{Discussion}

ASD is a complex neurodevelopmental disorder [3], and studies of animal models and in humans demonstrate alterations in the immune system across the spectrum [2, $3,8,15,21-26]$. Several studies correlate ASD symptoms and immune status [28-48, 50-53], supporting the hypothesis that there is a subgroup of ASD individuals who could benefit from immune-based therapies $[2,3,8,21-$ $24,26,54-56]$.

The ability of anti-inflammation/immunological modulation has been proposed in drugs routinely used for neurological and psychiatric diseases aside from their original mechanism of action. Aripiprazole, an antipsychotic approved by the FDA for use in ASD [14], has dis-

Immunological Therapy in ASD played immunological properties in in vitro experiments [195] and it limits inflammatory processes by enhancing the anti-inflammatory signaling in schizophrenia [196]. Valproic acid, a short-chain fatty acid used as a mood stabilizer and antiepileptic drug [197], may have anti-inflammatory as well as antioxidative effects [198-200].

The potential role of serotonergic transmission and NMDA receptors in the modulation of neuroinflammation has also been studied and could open new therapeutic perspectives to address the behavioral deficits in ASD [24, 54]. Buspirone [95, 201-203], fluoxetine [204-208], escitalopram [209, 210], citalopram [211], sertraline [212-214], D cycloserine [186, 215-218], amantadine [219], and memantine [220-222] have already been used in clinical research into autism. Finally, naltrexone, a potent opiate antagonist tested in ASD for improving behavioral changes [223-239], could also possess immunomodulatory action [240].

Currently, no available therapy can reverse the core symptoms of autism. The use of immune-based therapies may be a possible treatment route for some individuals, but only a few studies aimed at immunomodulation have been performed on ASD patients. These studies cover an extensive range of drug classes, including plant products, dietary supplements, probiotics, antibiotics, anti-inflammatory agents, immunomodulators, cell therapies, and even curious substances such as camel milk [241, 242]. Most are case reports or open trials with no control group. Only a few are placebo-controlled and have a sufficient number of participants to generate reliable findings. The heterogeneity of the study populations (regarding age, ethnic origin, and the severity of symptoms), the disparity in ASD diagnostic criteria, and the variety of psychological evaluation tools make it difficult to compare findings. In addition, many of the reports show important methodological flaws. Conflicting results in different studies on the same therapy are also frequent, and ASD symptoms showing improvement vary considerably. Lastly, there are only a few publications on each intervention, so further studies are needed to obtain consistent data.

It is possible that only some patients in the studies had immune dysfunction contributing to their etiology. Consequently, positive responses to a specific therapy in these patients could be overlooked when they are analyzed in a pool with nonresponders. The development of potential biomarkers of immune dysregulation and their correlation with phenotypic variability should increase the possibility of preselecting patients with a greater potential for improvement with immunomodulatory intervention. In- 
Fig. 1. Immunological endophenotypes in autism. The identification of specific markers related to different ASD subgroups may assist in reducing the heterogeneity of participants in clinical trials. In addition, animal model trials enable the translational study of new drugs, possible targets, and biomarkers.

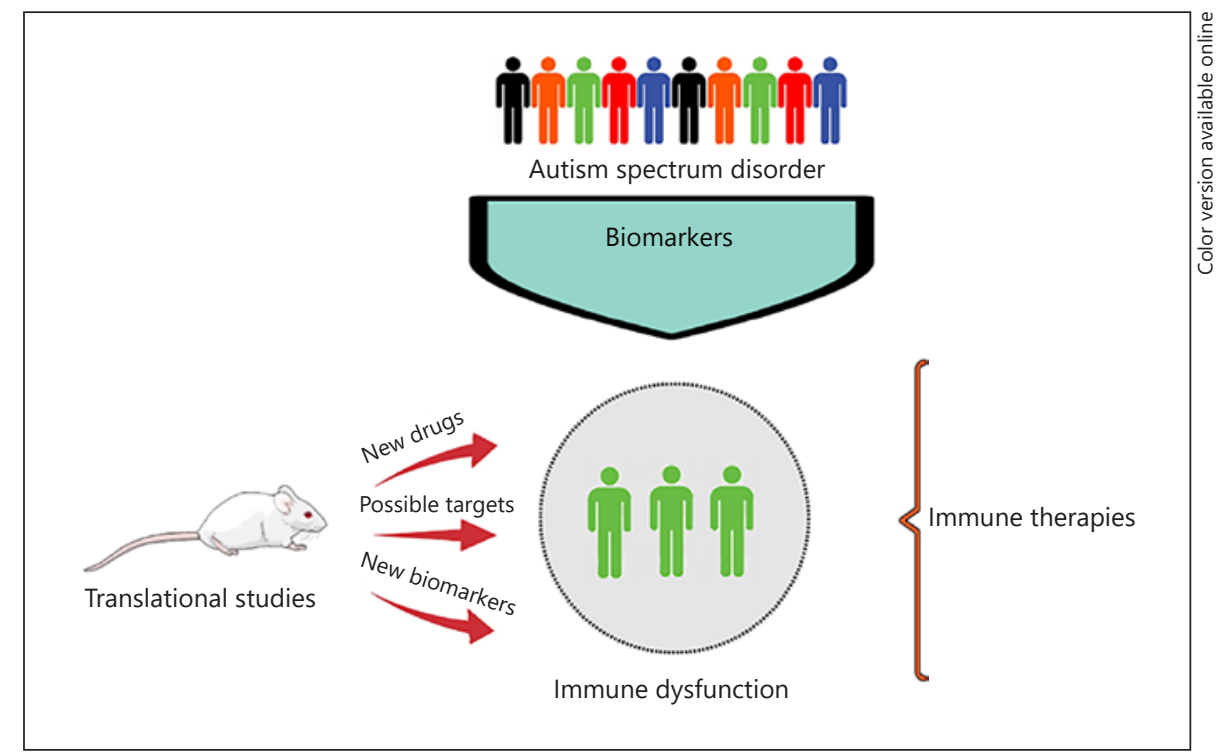

flammatory markers, including miRNA targets, appear to have potential for the development of individualized treatment strategies in the future [3, 243-247] (Fig. 1).

Despite the discrepancies in results and the methodological limitations found in the studies cited in this review, the possible existence of a subgroup of ASD patients who are true responders to immunological treatment cannot be excluded. Studies to investigate this possibility must be carried out, and the effectiveness of therapies previously tested on humans or in animal models should be evaluated. Drugs with anti-inflammatory potential such as donepezil, resveratrol, and fingolimod have demonstrated positive findings in animal models of ASD [248-255], pointing to promising therapeutic potential, so we would encourage further research to be undertaken.

\section{Conclusions}

The development of effective therapies in ASD is urgent. Despite immune dysfunction being a possible pathway for drug intervention in a subgroup of ASD individuals, few studies aiming an immunomodulatory action were performed. Besides, the use of potential biomarkers as screening tools may enable the selection of specific subjects for clinical trials and, in the future, determine which patients could benefit from a particular therapy. Most of the studies included in this review are not placebo-controlled and use different methodologies, making the in- terpretation of different results a challenge. Studies with a greater number of participants, randomized and placebo-controlled, either with interventions already described in humans or with new therapies from translational studies in animal models are needed.

\section{Acknowledgements}

We are grateful to the Postgraduate Program in Child and Adolescent Health, School of Medicine (UFRGS) and Translational Research Group in Autism Spectrum Disorder (GETTEA- UFRGS) for the opportunity to work on the project.

\section{Disclosure Statement}

The authors declare that the research was conducted in the absence of any commercial or financial relationships that could be construed as a potential conflict of interest.

\section{References}

1 American Psychiatric Association: Diagnostic and Statistical Manual of Mental Disorders, ed 5 (DSM- $\left.5^{\mathrm{TM}}\right)$. Arlington, American Psychiatric Publishing, 2013.

2 Gottfried C, Bambini-Junior V, Francis F, Riesgo R, Savino W: The impact of neuroimmune alterations in autism spectrum disorder. Front Psychiatry 2015;6:121.

3 Noriega DB, Savelkoul HFJ: Immune dysregulation in autism spectrum disorder. Eur J Pediatr 2014;173:33-43. 
4 Baio J, Wiggins L, Christensen DL, Maenner MJ, Daniels J, Warren Z, et al: Prevalence of autism spectrum disorder among children aged 8 years - Autism and Developmental Disabilities Monitoring Network, 11 Sites, United States, 2014. MMWR Surveill Summ 2018;67:1-23.

5 Brentani H, Paula CS, Bordini D, Rolim D, Sato F, Portolese J, et al: Autism spectrum disorders: an overview on diagnosis and treatment. Rev Bras Psiquiatr 2013;35:S62-S72.

6 Baxter AJ, Brugha TS, Erskine HE, Scheurer RW, Vos T, Scott JG: The epidemiology and global burden of autism spectrum disorders. Psychol Med 2015;45:601-613.

7 Benvenuto A, Battan B, Porfirio MC, Curatolo P: Pharmacotherapy of autism spectrum disorders. Brain Dev 2013;35:119-127.

8 Mead J, Ashwood P: Evidence supporting an altered immune response in ASD. Immunol Lett 2015;163:49-55.

9 Rossignol DA: Novel and emerging treatments for autism spectrum disorders: a systematic review. Ann Clin Psychiatry 2009;21: 213-236.

10 Kaplan G, McCracken JT: Psychopharmacology of autism spectrum disorders. Pediatr Clin North Am 2012;59:175-187.

11 Marcus RN, Owen R, Kamen L, Manos G, McQuade RD, Carson WH, et al: A placebocontrolled, fixed-dose study of aripiprazole in children and adolescents with irritability associated with autistic disorder. J Am Acad Child Adolesc Psychiatry 2009;48:1110-1119.

12 Owen R, Sikich L, Marcus RN, Corey-Lisle P, Manos G, McQuade RD, et al: Aripiprazole in the treatment of irritability in children and adolescents with autistic disorder. Pediatrics 2009;124:1533-1540.

13 Research Units on Pediatric Psychopharmacology Autism Network: Randomized, controlled, crossover trial of methylphenidate in pervasive developmental disorders with hyperactivity. Arch Gen Psychiatry 2005;62: 1266-1274.

14 LeClerc S, Easley D: Pharmacological therapies for autism spectrum disorder: a review. P T. 2015;40:389-397.

15 Masi A, Glozier N, Dale R, Guastella AJ: The immune system, cytokines, and biomarkers in autism spectrum disorder. Neurosci Bull 2017;33:194-204.

16 Buescher AVS, Cidav Z, Knapp M, Mandell DS: Costs of autism spectrum disorders in the United Kingdom and the United States. JAMA Pediatr 2014;168:721.

17 Karst JS, Van Hecke AV: Parent and family impact of autism spectrum disorders: a review and proposed model for intervention evaluation. Clin Child Fam Psychol Rev 2012;15: 247-277.

18 Smith LE, Greenberg JS, Mailick MR: The family context of autism spectrum disorders: influence on the behavioral phenotype and quality of life. Child Adolesc Psychiatr Clin N Am 2014;23:143-155.
19 Weiss JA, Cappadocia MC, MacMullin JA, Viecili M, Lunsky Y: The impact of child problem behaviors of children with ASD on parent mental health: the mediating role of acceptance and empowerment. Autism Int J Res Pract 2012;16:261-274.

20 Marchezan J, Becker M, Schwartsmann G, Ohlweiler L, Roesler R, Renck LB, et al: A placebo-controlled crossover trial of gastrin-releasing peptide in childhood autism. Clin Neuropharmacol 2017;40:108-112.

21 Verkhratsky A, Rodríguez JJ, Parpura V: Neuroglia in ageing and disease. Cell Tissue Res 2014;357:493-503.

22 Careaga M, Van de Water J, Ashwood P: Immune dysfunction in autism: a pathway to treatment. Neurotherapeutics 2010;7:283292.

23 McDougle CJ, Landino SM, Vahabzadeh A, O'Rourke J, Zurcher NR, Finger BC, et al: Toward an immune-mediated subtype of autism spectrum disorder. Brain Res 2015;1617:7292.

24 Chez MG, Guido-Estrada N: Immune therapy in autism: historical experience and future directions with immunomodulatory therapy. Neurotherapeutics 2010;7:293-301.

25 Masi A, Quintana DS, Glozier N, Lloyd AR, Hickie IB, Guastella AJ: Cytokine aberrations in autism spectrum disorder: a systematic review and meta-analysis. Mol Psychiatry 2015; 20:440-446.

26 Gładysz D, Krzywdzińska A, Hozyasz KK: Immune abnormalities in autism spectrum disorder - could they hold promise for causative treatment? Mol Neurobiol 2018;55: 6387-6435.

27 Stubbs EG: Autistic children exhibit undetectable hemagglutination-inhibition antibody titers despite previous Rubella vaccination. J Autism Child Schizophr 1976;6:269274.

28 Yang C-J, Liu C-L, Sang B, Zhu X-M, Du Y-J: The combined role of serotonin and interleukin- 6 as biomarker for autism. Neuroscience 2015;284:290-296.

29 Ashwood P, Krakowiak P, Hertz-Picciotto I, Hansen R, Pessah I, Van de Water J: Elevated plasma cytokines in autism spectrum disorders provide evidence of immune dysfunction and are associated with impaired behavioral outcome. Brain Behav Immun 2011;25:4045.

30 Jyonouchi H, Geng L, Ruby A, ZimmermanBier B: Dysregulated innate immune responses in young children with autism spectrum disorders: their relationship to gastrointestinal symptoms and dietary intervention. Neuropsychobiology 2005;51:77-85.

31 Jyonouchi H, Geng L, Davidow AL: Cytokine profiles by peripheral blood monocytes are associated with changes in behavioral symptoms following immune insults in a subset of ASD subjects: an inflammatory subtype? J Neuroinflammation 2014;11:187.
32 El-Ansary A, Hassan WM, Qasem H, Das $\mathrm{UN}$ : Identification of biomarkers of impaired sensory profiles among autistic patients. PLoS One 2016;11:e0164153.

33 Ferguson BJ, Marler S, Altstein LL, Lee EB, Mazurek MO, McLaughlin A, et al: Associations between cytokines, endocrine stress response, and gastrointestinal symptoms in autism spectrum disorder. Brain Behav Immun 2016;58:57-62.

34 Careaga M, Rogers S, Hansen RL, Amaral DG, Van de Water J, Ashwood P: Immune endophenotypes in children with autism spectrum disorder. Biol Psychiatry 2017;81:434-441.

35 Al-Ayadhi LY: Pro-inflammatory cytokines in autistic children in central Saudi Arabia. Neurosciences (Riyadh) 2005;10:155-158.

36 Ricci S, Businaro R, Ippoliti F, Lo Vasco VR, Massoni F, Onofri E, et al: Altered cytokine and BDNF levels in autism spectrum disorder. Neurotox Res 2013;24:491-501.

37 Makinodan M, Iwata K, Ikawa D, Yamashita Y, Yamamuro K, Toritsuka M, et al: Tumor necrosis factor- $\alpha$ expression in peripheral blood mononuclear cells correlates with early childhood social interaction in autism spectrum disorder. Neurochem Int 2017;104:1-5.

38 Han YMY, Cheung WKY, Wong CK, Sze SL, Cheng TWS, Yeung MK, et al: Distinct cytokine and chemokine profiles in autism spectrum disorders. Front Immunol 2017;8:11.

39 Ashwood P, Krakowiak P, Hertz-Picciotto I, Hansen R, Pessah IN, Van de Water J: Associations of impaired behaviors with elevated plasma chemokines in autism spectrum disorders. J Neuroimmunol 2011;232:196-199.

40 Ashwood P, Enstrom A, Krakowiak P, HertzPicciotto I, Hansen RL, Croen LA, et al: Decreased transforming growth factor $\beta 1$ in autism: a potential link between immune dysregulation and impairment in clinical behavioral outcomes. J Neuroimmunol 2008; 204:149-153.

41 El Gohary TM, El Aziz NA, Darweesh M, Sadaa ES: Plasma level of transforming growth factor $\beta 1$ in children with autism spectrum disorder. Egypt J Ear Nose Throat Allied Sci 2015;16:69-73.

42 AL-Ayadhi LY, Mostafa GA: Elevated serum levels of macrophage-derived chemokine and thymus and activation-regulated chemokine in autistic children. J Neuroinflamm 2013;10: 846.

43 Al-Ayadhi LY, Mostafa GA: Elevated serum levels of interleukin-17A in children with autism. J Neuroinflamm 2012;9:158.

44 Enstrom A, Onore C, Hertz-Picciotto I, Hansen R, Croen L, Van de Water J, et al: Detection of IL-17 and IL-23 in plasma samples of children with autism. Am J Biochem Biotechnol 2008;4:114-120.

45 Rose D, Van de Water J, Ashwood P: Abstract \# 1787 Unique immune profiles in children with autism who experience gastrointestinal co-morbidity. Brain Behav Immun 2016; $57: \mathrm{e} 23-\mathrm{e} 24$ 
46 Napolioni V, Ober-Reynolds B, Szelinger S, Corneveaux JJ, Pawlowski T, Ober-Reynolds $\mathrm{S}$, et al: Plasma cytokine profiling in sibling pairs discordant for autism spectrum disorder. J Neuroinflamm 2013;10:38.

47 Heuer L, Ashwood P, Schauer J, Goines P, Krakowiak P, Hertz-Picciotto I, et al: Reduced levels of immunoglobulin in children with autism correlates with behavioral symptoms. Autism Res Off J Int Soc Autism Res 2008;1: 275-283.

48 Hollander E, DelGiudice-Asch G, Simon L, Schmeidler J, Cartwright C, DeCaria CM, et al: $B$ lymphocyte antigen $\mathrm{D} 8 / 17$ and repetitive behaviors in autism. Am J Psychiatry 1999; 156:317-320.

49 Mostafa GA, Al-Ayadhi LY: The relationship between the increased frequency of serum antineuronal antibodies and the severity of autism in children. Eur J Paediatr Neurol 2012; 16:464-468.

50 Goines P, Haapanen L, Boyce R, Duncanson P, Braunschweig D, Delwiche L, et al: Autoantibodies to cerebellum in children with autism associate with behavior. Brain Behav Immun 2011;25:514-523.

51 Piras IS, Haapanen L, Napolioni V, Sacco R, Van de Water J, Persico AM: Anti-brain antibodies are associated with more severe cognitive and behavioral profiles in Italian children with autism spectrum disorder. Brain Behav Immun 2014:38:91-99.

52 Mostafa GA, Al-Ayadhi LY: Increased serum levels of anti-ganglioside M1 auto-antibodies in autistic children: relation to the disease severity. J Neuroinflammation 2011;8:39.

53 Braunschweig D, Duncanson P, Boyce R, Hansen R, Ashwood P, Pessah IN, et al: Behavioral correlates of maternal antibody status among children with autism. J Autism Dev Disord 2012;42:1435-1445.

54 Lacivita E, Perrone R, Margari L, Leopoldo M: Targets for drug therapy for autism spectrum disorder: challenges and future directions. J Med Chem 2017;60:9114-9141.

55 Estes ML, McAllister AK: Immune mediators in the brain and peripheral tissues in autism spectrum disorder. Nat Rev Neurosci 2015; 16:469-486.

56 Meltzer A, Van de Water J: The role of the immune system in autism spectrum disorder. Neuropsychopharmacology 2017;42: 284-298.

57 Tarozzi A, Angeloni C, Malaguti M, Morroni F, Hrelia S, Hrelia P: Sulforaphane as a potential protective phytochemical against neurodegenerative diseases. Oxid Med Cell Longev 2013;2013:415078.

58 Juge N, Mithen RF, Traka M: Molecular basis for chemoprevention by sulforaphane: a comprehensive review. Cell Mol Life Sci 2007;64: $1105-1127$.

59 Singh K, Connors SL, Macklin EA, Smith KD, Fahey JW, Talalay P, et al: Sulforaphane treatment of autism spectrum disorder (ASD). Proc Natl Acad Sci USA 2014;111:1555015555.
60 Lynch R, Diggins EL, Connors SL, Zimmerman AW, Singh K, Liu H, et al: Sulforaphane from broccoli reduces symptoms of autism: a follow-up case series from a randomized double-blind study. Glob Adv Heal Med 2017;6: $2164957 X 17735826$.

61 Sareddy GR, Geeviman K, Ramulu C, Babu PP: The nonsteroidal anti-inflammatory drug celecoxib suppresses the growth and induces apoptosis of human glioblastoma cells via the NF-kB pathway. J Neurooncol 2012;106:99109.

62 Arias-Negrete S, Keller K, Chadee K: Proinflammatory cytokines regulate cyclooxygenase-2 mRNA expression in human macrophages. Biochem Biophys Res Commun 1995; 208:582-589.

63 Asadabadi M, Mohammadi M-R, Ghanizadeh A, Modabbernia A, Ashrafi M, Hassanzadeh E, et al: Celecoxib as adjunctive treatment to risperidone in children with autistic disorder: a randomized, double-blind, placebocontrolled trial. Psychopharmacology 2013; 225:51-59.

64 Pulte ED, Dmytrijuk A, Nie L, Goldberg KB, McKee AE, Farrell AT, et al: FDA approval summary: lenalidomide as maintenance therapy after autologous stem cell transplant in newly diagnosed multiple myeloma. Oncologist 2018;23:734-739.

65 Chez M, Low R, Parise C, Donnel T: Safety and observations in a pilot study of lenalidomide for treatment in autism. Autism Res Treat 2012;2012:291601.

66 Kreth S, Ledderose C, Luchting B, Weis F, Thiel M: Immunomodulatory properties of pentoxifylline are mediated via adenosine-dependent pathways. Shock 2010;34:10-16.

67 Dolatabadi HRD, Zarrindast MR, Reisi P, Nasehi M: The effects of pentoxifylline on serum levels of interleukin 10 and interferon gamma and memory function in lipopolysaccharide-induced inflammation in rats. Adv Biomed Res 2017;6:110.

68 Gupta S, Rimland B, Shilling PD: Pentoxifylline: brief review and rationale for its possible use in the treatment of autism. J Child Neurol 1996;11:501-504.

69 Gupta S: Immunological treatments for autism. J Autism Dev Disord 2000;30:475-479.

70 Sogame S: Clinical experiences with the administration of pentoxifylline against autism and behavior abnormalities. Jpn J Child Psych 1978;137-144.

71 Nakane A: Effect of pentoxifylline in autistic children. Tokyoto Eisei Gakkashi 1980;104105.

72 Shimoide M: Effect of pentoxifylline (Trental) on infantile autism. Clin Exp Med 1981;285288.

73 Turek S: Treatment of psychotic and autistic children with pentoxifylline. ASANA 1981; 51-60.

74 Suzuki M, Nakashita Y, Ogawa T: Sugiyama $A$, et al: On the effects of pentoxifylline upon the EEG activity of early infantile autism. Brain Dev 1984;6:156.
75 Akhondzadeh S, Fallah J, Mohammadi M-R, Imani R, Mohammadi M, Salehi B, et al: Double-blind placebo-controlled trial of pentoxifylline added to risperidone: effects on aberrant behavior in children with autism. Prog Neuropsychopharmacol Biol Psychiatry 2010;34:32-36.

76 Pérez JCJ, Ramírez AC, González LT, Espinosa LEM, Quintana MMP, Galván GA, et al: Spironolactone effect in hepatic ischemia/reperfusion injury in Wistar rats. Oxid Med Cell Longev 2016;2016:3196431.

77 Miura R, Nakamura K, Miura D, Miura A, Hisamatsu K, Kajiya M, et al: Anti-inflammatory effect of spironolactone on human peripheral blood mononuclear cells. J Pharmacol Sci 2006;101:256-259.

78 Miura R, Nakamura K, Miura D, Miura A, Hisamatsu K, Kajiya M, et al: Aldosterone synthesis and cytokine production in human peripheral blood mononuclear cells. J Pharmacol Sci 2006;102:288-295.

79 Bendtzen K, Hansen PR, Rieneck K: Spironolactone inhibits production of proinflammatory cytokines, including tumour necrosis factor-alpha and interferon-gamma, and has potential in the treatment of arthritis. Clin Exp Immunol 2003;134:151-158.

80 Kato Y, Kamiya H, Koide N, Odkhuu E, Komatsu T, Dagvadorj J, et al: Spironolactone inhibits production of proinflammatory mediators in response to lipopolysaccharide via inactivation of nuclear factor- $\mathrm{\kappa B}$. Immunopharmacol Immunotoxicol 2014;36:237-241.

81 Bradstreet JJ, Smith S, Granpeesheh D, ElDahr JM, Rossignol D: Spironolactone might be a desirable immunologic and hormonal intervention in autism spectrum disorders. Med Hypotheses 2007;68:979-987.

82 Middleton E, Kandaswami C, Theoharides TC: The effects of plant flavonoids on mammalian cells: implications for inflammation, heart disease, and cancer. Pharmacol Rev 2000;52:673-751.

83 López-Lázaro M: Distribution and biological activities of the flavonoid luteolin. Mini Rev Med Chem 2009;9:31-59.

84 Kempuraj D, Madhappan B, Christodoulou S, Boucher W, Cao J, Papadopoulou N, et al: Flavonols inhibit proinflammatory mediator release, intracellular calcium ion levels and protein kinase $\mathrm{C}$ theta phosphorylation in human mast cells. Br J Pharmacol 2005;145:934-944.

85 Theoharides TC, Asadi S, Panagiotidou S: A case series of a luteolin formulation (NeuroProtek $^{\circledR}$ ) in children with autism spectrum disorders. Int J Immunopathol Pharmacol 2012;25:317-323.

86 Taliou A, Zintzaras E, Lykouras L, Francis K: An open-label pilot study of a formulation containing the anti-inflammatory flavonoid luteolin and its effects on behavior in children with autism spectrum disorders. Clin Ther 2013;35:592-602.

Marchezan/Winkler dos Santos/

Deckmann/Riesgo 
87 Tsilioni I, Taliou A, Francis K, Theoharides TC: Children with autism spectrum disorders, who improved with a luteolin-containing dietary formulation, show reduced serum levels of TNF and IL-6. Transl Psychiatry 2015;5:e647.

88 Bertolino B, Crupi R, Impellizzeri D, Bruschetta G, Cordaro M, Siracusa R, et al: Beneficial effects of co-ultramicronized palmitoylethanolamide/luteolin in a mouse model of autism and in a case report of autism. CNS Neurosci Ther 2017;23:87-98.

89 Schweingruber N, Reichardt SD, Lühder F, Reichardt HM: Mechanisms of glucocorticoids in the control of neuroinflammation. J Neuroendocrinol 2012;24:174-182.

90 Duffy FH, Shankardass A, McAnulty GB, Eksioglu YZ, Coulter D, Rotenberg A, et al: Corticosteroid therapy in regressive autism: a retrospective study of effects on the frequency modulated auditory evoked response (FMAER), language, and behavior. BMC Neurol 2014;14:70.

91 Shenoy S, Arnold S, Chatila T: Response to steroid therapy in autism secondary to autoimmune lymphoproliferative syndrome. J Pediatr 2000;136:682-687.

92 Stefanatos GA, Grover W, Geller E: Case study: corticosteroid treatment of language regression in pervasive developmental disorder. J Am Acad Child Adolesc Psychiatry 1995;34:1107-1111.

93 Mordekar SR, Prendergast M, Chattopadhyay AK, Baxter PS: Corticosteroid treatment of behaviour, language and motor regression in childhood disintegrative disorder. Eur J Paediatr Neurol 2009;13:367-369.

94 Buitelaar JK, Dekker ME, van Ree JM, van Engeland H: A controlled trial with ORG 2766, an ACTH-(4-9) analog, in 50 relatively able children with autism. Eur Neuropsychopharmacol 1996;6:13-19.

95 Buitelaar JK, van Engeland H, de Kogel K, de Vries H, van Hooff J, van Ree J: The adrenocorticotrophic hormone (4-9) analog ORG 2766 benefits autistic children: report on a second controlled clinical trial. J Am Acad Child Adolesc Psychiatry 1992;31:1149-1156.

96 Buitelaar JK, van Engeland H, de Kogel KH, de Vries H, van Hooff JA, van Ree JM: The use of adrenocorticotrophic hormone (4-9) ana$\log$ ORG 2766 in autistic children: effects on the organization of behavior. Biol Psychiatry 1992;31:1119-1129.

97 Buitelaar JK, van Engeland H, van Ree JM, de Wied D: Behavioral effects of Org 2766, a synthetic analog of the adrenocorticotrophic hormone (4-9), in 14 outpatient autistic children. J Autism Dev Disord 1990;20:467-478.

98 Verbaten MN, Kemner C, Buitelaar JK, van Ree JM, van Beijsterveld CE, van Engeland H: Effects of ORG-2766 on brain event-related potentials of autistic children. Psychiatry Res 1996;63:33-45.
99 Fung LK, Libove RA, Phillips J, Haddad F, Hardan AY: Brief report: an open-label study of the neurosteroid pregnenolone in adults with autism spectrum disorder. J Autism Dev Disord 2014;44:2971-2977.

100 Marx CE, Keefe RSE, Buchanan RW, Hamer RM, Kilts JD, Bradford DW, et al: Proof-ofconcept trial with the neurosteroid pregnenolone targeting cognitive and negative symptoms in schizophrenia. Neuropsychopharmacology 2009;34:1885-1903.

101 Jasion VS, Burnett BP: Survival and digestibility of orally-administered immunoglobulin preparations containing IgG through the gastrointestinal tract in humans. Nutr J 2015;14:22.

102 Schneider CK, Melmed RD, Barstow LE, Enriquez FJ, Ranger-Moore J, Ostrem JA: Oral human immunoglobulin for children with autism and gastrointestinal dysfunction: a prospective, open-label study. J Autism Dev Disord 2006;36:1053-1064.

103 Handen BL, Melmed RD, Hansen RL, Aman MG, Burnham DL, Bruss JB, et al: A doubleblind, placebo-controlled trial of oral human immunoglobulin for gastrointestinal dysfunction in children with autistic disorder. J Autism Dev Disord 2009;39:796-805.

104 Rütter A, Luger TA: High-dose intravenous immunoglobulins: an approach to treat severe immune-mediated and autoimmune diseases of the skin. J Am Acad Dermatol 2001;44:1010-1024.

105 Niederhofer H, Staffen W, Mair A: Immunoglobulins as an alternative strategy of psychopharmacological treatment of children with autistic disorder. Neuropsychopharmacology 2003;28:1014-1015.

106 DelGiudice-Asch G, Simon L, Schmeidler J, Cunningham-Rundles C, Hollander E: Brief report: a pilot open clinical trial of intravenous immunoglobulin in childhood autism. J Autism Dev Disord 1999;29:157-160.

107 Plioplys AV: Intravenous immunoglobulin treatment of children with autism. J Child Neurol 1998;13:79-82.

108 Melamed IR, Heffron M, Testori A, Lipe K: A pilot study of high-dose intravenous immunoglobulin 5\% for autism: impact on autism spectrum and markers of neuroinflammation. Autism Res 2018;11:421-433.

109 Siniscalco D, Bradstreet JJ, Antonucci N: Therapeutic role of hematopoietic stem cells in autism spectrum disorder-related inflammation. Front Immunol 2013;4:140.

110 Lv Y-T, Zhang Y, Liu M, Qiuwaxi J, Ashwood P, Cho SC, et al: Transplantation of human cord blood mononuclear cells and umbilical cord-derived mesenchymal stem cells in autism. J Transl Med 2013;11:196.

111 Bradstreet JJ, Sych N, Antonucci N, Klunnik $\mathrm{M}$, Ivankova O, Matyashchuk I, et al: Efficacy of fetal stem cell transplantation in autism spectrum disorders: an open-labeled pilot study. Cell Transplant 2014;23(suppl 1):S105-S112.
112 Sharma A, Badhe P, Gokulchandran N Kulkarni P, Mishra P, Shetty A, et al: An improved case of autism as revealed by PET CT scan in patient transplanted with autologous bone marrow derived mononuclear cells. J Stem Cell Res Ther 2013;3:139.

113 Sharma A, Gokulchandran N, Sane H, Nagrajan A, Paranjape A, Kulkarni P, et al: Autologous bone marrow mononuclear cell therapy for autism: an open label proof of concept study. Stem Cells Int 2013;2013: 623875.

114 Bansal H, Verma P, Agrawal A, Leon J, Sundell IB, Koka PS: A Short study report on bone marrow aspirate concentrate cell therapy in ten South Asian Indian patients with autism. J Stem Cells 2016;11:25-36.

115 Dawson G, Sun JM, Davlantis KS, Murias M, Franz L, Troy J, et al: Autologous cord blood infusions are safe and feasible in young children with autism spectrum disorder: results of a single-center phase I open-label trial. Stem Cells Transl Med 2017;6:1332-1339.

116 Shroff G: Human embryonic stem cells in the treatment of autism: a case series. Innov Clin Neurosci 2017;14:12-16.

117 Arnaudov A, Kostova Z: Dialysable leukocyte extracts in immunotherapy. Biotechnol Biotechnol Equip 2015;29:1017-1023.

118 Fudenberg HH: Dialysable lymphocyte extract (DLyE) in infantile onset autism: a pilot study. Biotherapy 1996;9:143-147.

119 Soczynska JK, Mansur RB, Brietzke E, Swardfager W, Kennedy SH, Woldeyohannes HO, et al: Novel therapeutic targets in depression: minocycline as a candidate treatment. Behav Brain Res 2012;235:302317.

120 Rosenblat JD, McIntyre RS: Efficacy and tolerability of minocycline for depression: a systematic review and meta-analysis of clinical trials. J Affect Disord 2018;227:219-225.

121 Kim H-S, Suh Y-H: Minocycline and neurodegenerative diseases. Behav Brain Res 2009; 196:168-179.

122 Orsucci D, Calsolaro V, Mancuso M, Siciliano G: Neuroprotective effects of tetracyclines: molecular targets, animal models and human disease. CNS Neurol Disord Drug Targets 2009;8:222-231.

123 Yong VW, Wells J, Giuliani F, Casha S, Power C, Metz LM: The promise of minocycline in neurology. Lancet Neurol 2004;3:744751.

124 Paribello C, Tao L, Folino A, Berry-Kravis E Tranfaglia M, Ethell IM, et al: Open-label add-on treatment trial of minocycline in fragile X syndrome. BMC Neurol 2010;10: 91.

125 Leigh MJS, Nguyen DV, Mu Y, Winarni TI, Schneider A, Chechi T, et al: A randomized double-blind, placebo-controlled trial of minocycline in children and adolescents with fragile X syndrome. J Dev Behav Pediatr JDBP 2013;34:147-155. 
126 Pardo CA, Buckley A, Thurm A, Lee L-C, Azhagiri A, Neville DM, et al: A pilot openlabel trial of minocycline in patients with autism and regressive features. J Neurodev Disord 2013;5:9.

127 Ghaleiha A, Alikhani R, Kazemi M-R, Mohammadi M-R, Mohammadinejad P, Zeinoddini A, et al: Minocycline as adjunctive treatment to risperidone in children with autistic disorder: a randomized, doubleblind placebo-controlled trial. J Child Adolesc Psychopharmacol 2016;26:784-791.

128 Derosa G, Sahebkar A, Maffioli P: The role of various peroxisome proliferator-activated receptors and their ligands in clinical practice. J Cell Physiol 2018;233:153-161.

129 Yandrapalli S, Aronow WS: Cardiovascular benefits of the newer medications for treating type 2 diabetes mellitus. J Thorac Dis 2017;9:2124-2134.

130 Yessoufou A, Wahli W: Multifaceted roles of peroxisome proliferator-activated receptors (PPARs) at the cellular and whole organism levels. Swiss Med Wkly 2010;140:w13071.

131 Rogliani P, Ora J, Di Daniele N, Lauro D: Pleiotropic effects of hypoglycemic agents: implications in asthma and COPD. Curr Opin Pharmacol 2018;40:34-38.

132 Nierenberg AA, Ghaznavi SA, Sande Mathias I, Ellard KK, Janos JA, Sylvia LG: Peroxisome proliferator-activated receptor gamma coactivator-1 alpha as a novel target for bipolar disorder and other neuropsychiatric disorders. Biol Psychiatry 2018;83:761-769.

133 Boris M, Kaiser CC, Goldblatt A, Elice MW, Edelson SM, Adams JB, et al: Effect of pioglitazone treatment on behavioral symptoms in autistic children. J Neuroinflamm 2007;4:3.

134 Ghaleiha A, Rasa SM, Nikoo M, Farokhnia M, Mohammadi M-R, Akhondzadeh S: A pilot double-blind placebo-controlled trial of pioglitazone as adjunctive treatment to risperidone: effects on aberrant behavior in children with autism. Psychiatry Res 2015; 229:181-187.

135 McCracken JT, McGough J, Shah B, Cronin P, Hong D, Aman MG, et al: Risperidone in children with autism and serious behavioral problems. N Engl J Med 2002;347:314-321.

136 Noto C, Ota VK, Gouvea ES, Rizzo LB, Spindola LMN, Honda PHS, et al: Effects of risperidone on cytokine profile in drug-naïve first-episode psychosis. Int J Neuropsychopharmacol 2014;18:pii: pyu042.

137 Baumeister D, Ciufolini S, Mondelli V: Effects of psychotropic drugs on inflammation: consequence or mediator of therapeutic effects in psychiatric treatment? Psychopharmacology 2016;233:1575-1589.

138 MacDowell KS, García-Bueno B, Madrigal JLM, Parellada M, Arango C, Micó JA, et al: Risperidone normalizes increased inflammatory parameters and restores anti-inflammatory pathways in a model of neuroinflammation. Int J Neuropsychopharmacol 2013;16:121-135.
139 Choi JE, Widjaja F, Careaga M, Bent S, Ashwood P, Hendren RL: Change in plasma cytokine levels during risperidone treatment in children with autism. J Child Adolesc Psychopharmacol 2014;24:586-589.

140 Tobiasova Z, van der Lingen KHB, Scahill L, Leckman JF, Zhang Y, Chae W, et al: Risperidone-related improvement of irritability in children with autism is not associated with changes in serum of epidermal growth factor and interleukin-13. J Child Adolesc Psychopharmacol 2011;21:555-564.

141 Mostafa GA, Al-Ayadhi LY: Reduced serum concentrations of 25-hydroxy vitamin D in children with autism: relation to autoimmunity. J Neuroinflamm 2012;9:201.

142 Saad K, Abdel-Rahman AA, Elserogy YM, Al-Atram AA, Cannell JJ, Bjørklund G, et al: Vitamin D status in autism spectrum disorders and the efficacy of vitamin D supplementation in autistic children. Nutr Neurosci 2016;19:346-351.

143 Meguid NA, Hashish AF, Anwar M, Sidhom G: Reduced serum levels of 25-hydroxy and 1,25-dihydroxy vitamin D in Egyptian children with autism. J Altern Complement Med 2010;16:641-645.

144 Tostes MHF de S, Polonini HC, Gattaz WF, Raposo NRB, Baptista EB: Low serum levels of 25-hydroxyvitamin D (25-OHD) in children with autism. Trends Psychiatry Psychother 2012;34:161-163.

145 Kočovská E, Andorsdóttir G, Weihe P, Halling J, Fernell E, Stóra T, et al: Vitamin D in the general population of young adults with autism in the Faroe islands. J Autism Dev Disord 2014;44:2996-3005.

146 Cannell JJ: Autism, will vitamin D treat core symptoms? Med Hypotheses 2013;81:195198.

147 Jia F, Wang B, Shan L, Xu Z, Staal WG, Du L: Core symptoms of autism improved after vitamin D supplementation. Pediatrics 2015;135:e196-e198.

148 Feng J, Shan L, Du L, Wang B, Li H, Wang $\mathrm{W}$, et al: Clinical improvement following vitamin $\mathrm{D}_{3}$ supplementation in autism spectrum disorder. Nutr Neurosci 2017;20:284290.

149 Kerley CP, Power C, Gallagher L, Coghlan $\mathrm{D}$ : Lack of effect of vitamin $\mathrm{D}_{3}$ supplementation in autism: a 20-week, placebo-controlled RCT. Arch Dis Child 2017;102:10301036.

150 Saad K, Abdel-Rahman AA, Elserogy YM, Al-Atram AA, El-Houfey AA, Othman HA$\mathrm{K}$, et al: Randomized controlled trial of vitamin D supplementation in children with autism spectrum disorder. J Child Psychol Psychiatry 2018;59:20-29.

151 Mazahery H, Stonehouse W, Delshad M, Kruger MC, Conlon CA, Beck KL, et al: Relationship between long chain n-3 polyunsaturated fatty acids and autism spectrum disorder: systematic review and meta-analysis of case-control and randomised controlled trials. Nutrients 2017;9:pii: E155.
152 Layé S, Nadjar A, Joffre C, Bazinet RP: Antiinflammatory effects of omega- 3 fatty acids in the brain: physiological mechanisms and relevance to pharmacology. Pharmacol Rev 2018;70:12-38.

153 Madore C, Leyrolle Q, Lacabanne C, Benmamar-Badel A, Joffre C, Nadjar A, et al: Neuroinflammation in autism: plausible role of maternal inflammation, dietary omega 3 , and microbiota. Neural Plast 2016;2016: 3597209.

154 SalLam M, Motaleb F, Ahmed M, Mahmoud A: Anti-inflammatory effect of omega-3 polyunsaturated fatty acids in children with bronchial asthma; relation to nuclear factorkappa B (NF-kB) and inflammatory cytokines IL-12 and IL-13. Egypt J Biochem Mol Biol 2010;28.

155 Zhang R, He G, Wang Y, Zhou K, Ma E: Omega-3 polyunsaturated fatty acids inhibit the increase in cytokines and chemotactic factors induced in vitro by lymph fluid from an intestinal ischemia-reperfusion injury model. Nutrition 2015;31:508-514.

156 Farjadian S, Moghtaderi M, Kalani M, Gholami T, Hosseini Teshnizi S: Effects of omega-3 fatty acids on serum levels of T-helper cytokines in children with asthma. Cytokine 2016;85:61-66.

157 Zhao Y, Joshi-Barve S, Barve S, Chen LH Eicosapentaenoic acid prevents LPS-induced TNF- $\alpha$ expression by preventing NF$\kappa B$ activation. J Am Coll Nutr 2004;23:7178.

158 Allam-Ndoul B, Guénard F, Barbier O, Vohl M-C: Effect of n-3 fatty acids on the expression of inflammatory genes in THP-1 macrophages. Lipids Health Dis 2016;15:69.

159 Posar A, Visconti P: Omega-3 supplementation in autism spectrum disorders: a still open question? J Pediatr Neurosci 2016;11: 225-227.

160 Posar A, Visconti P: Complementary and alternative medicine in autism: the question of omega-3. Pediatr Ann 2016;45:e103-e107.

161 Sathe N, Andrews JC, McPheeters ML, Warren ZE: Nutritional and dietary interventions for autism spectrum disorder: a systematic review. Pediatrics 2017; 139:e20170346.

162 Horvath A, Łukasik J, Szajewska H: $\omega-3$ Fatty acid supplementation does not affect autism spectrum disorder in children: a systematic review and meta-analysis. J Nutr 2017; 147:367-376.

163 Li Y-J, Li Y-M, Xiang D-X: Supplement intervention associated with nutritional deficiencies in autism spectrum disorders: a systematic review. Eur J Nutr 2017, DOI: 10.1007/s00394-017-1528-6.

164 Cheng Y-S, Tseng P-T, Chen Y-W, Stubbs B, Yang W-C, Chen T-Y, et al: Supplementation of omega 3 fatty acids may improve hyperactivity, lethargy, and stereotypy in children with autism spectrum disorders: a meta-analysis of randomized controlled trials. Neuropsychiatr Dis Treat 2017;13:2531-2543. 
165 Maclennan KM, Darlington CL, Smith PF: The CNS effects of Ginkgo biloba extracts and ginkgolide B. Prog Neurobiol 2002;67: 235-257.

166 Ernst E: The risk-benefit profile of commonly used herbal therapies: Ginkgo, St. John's Wort, Ginseng, Echinacea, Saw Palmetto, and Kava. Ann Intern Med 2002;136:42-53.

167 Niederhofer H: First preliminary results of an observation of Ginkgo biloba treating patients with autistic disorder. Phyther Res PTR 2009;23:1645-1646.

168 Hasanzadeh E, Mohammadi M-R, Ghanizadeh A, Rezazadeh S-A, Tabrizi M, Rezaei F, et al: A double-blind placebo-controlled trial of Ginkgo biloba added to risperidone in patients with autistic disorders. Child Psychiatry Hum Dev 2012;43:674-682.

169 Prokopieva VD, Yarygina EG, Bokhan NA, Ivanova SA: Use of carnosine for oxidative stress reduction in different pathologies. Oxid Med Cell Longev 2016;2016:2939087.

170 Stvolinsky SL, Kukley ML, Dobrota D, Matejovicova M, Tkac I, Boldyrev AA: Carnosine: an endogenous neuroprotector in the ischemic brain. Cell Mol Neurobiol 1999;19: 45-56.

171 Wang AM, Ma C, Xie ZH, Shen F: Use of carnosine as a natural anti-senescence drug for human beings. Biochemistry 2000;65: 869-871.

172 Fleisher-Berkovich S, Abramovitch-Dahan C, Ben-Shabat S, Apte R, Beit-Yannai E: Inhibitory effect of carnosine and $\mathrm{N}$-acetyl carnosine on LPS-induced microglial oxidative stress and inflammation. Peptides 2009;30: 1306-1312.

173 Hajizadeh-Zaker R, Ghajar A, Mesgarpour B, Afarideh M, Mohammadi M-R, Akhondzadeh S: L-Carnosine as an adjunctive therapy to risperidone in children with autistic disorder: a randomized, double-blind, placebo-controlled trial. J Child Adolesc Psychopharmacol 2018;28:74-81.

174 Chez MG, Buchanan CP, Aimonovitch MC, Becker M, Schaefer K, Black C, et al: Doubleblind, placebo-controlled study of L-carnosine supplementation in children with autistic spectrum disorders. J Child Neurol 2002; 17:833-837.

175 Mehrazad-Saber Z, Kheirouri S, Noorazar S-G: Effects of L-carnosine supplementation on sleep disorders and disease severity in autistic children: a randomized, controlled clinical trial. Basic Clin Pharmacol Toxicol 2018;123:72-77.

176 Atkuri KR, Mantovani JJ, Herzenberg LA, Herzenberg LA: $\mathrm{N}$-acetylcysteine - a safe antidote for cysteine/glutathione deficiency. Curr Opin Pharmacol 2007;7:355-359.

177 Deepmala null, Slattery J, Kumar N, Delhey L, Berk M, Dean O, et al: Clinical trials of Nacetylcysteine in psychiatry and neurology: a systematic review. Neurosci Biobehav Rev 2015;55:294-321.
178 Pinar Karapinar S, Ulum YZA, Ozcelik B, Dogan Buzoglu H, Ceyhan D, Balci Peynircioglu B, et al: The effect of N-acetylcysteine and calcium hydroxide on TNF- $\alpha$ and TGF- $\beta 1$ in lipopolysaccharide-activated macrophages. Arch Oral Biol 2016;68:4854.

179 Palacio JR, Markert UR, Martínez P: Antiinflammatory properties of $\mathrm{N}$-acetylcysteine on lipopolysaccharide-activated macrophages. Inflamm Res 2011;60:695-704.

180 Marler S, Sanders KB, Veenstra-VanderWeele J: $\mathrm{N}$-acetylcysteine as treatment for self-injurious behavior in a child with autism. J Child Adolesc Psychopharmacol 2014;24:231-234.

181 Stutzman D, Dopheide J: Acetylcysteine for treatment of autism spectrum disorder symptoms. Am J Heal Pharm 2015;72:19561959.

182 Ghanizadeh A, Derakhshan N: N-acetylcysteine for treatment of autism, a case report. J Res Med Sci 2012;17:985-987.

183 Hardan AY, Fung LK, Libove RA, Obukhanych TV, Nair S, Herzenberg LA, et al: A randomized controlled pilot trial of oral $\mathrm{N}$ acetylcysteine in children with autism. Biol Psychiatry 2012;71:956-961.

184 Ghanizadeh A, Moghimi-Sarani E: A randomized double-blind placebo controlled clinical trial of $\mathrm{N}$-acetylcysteine added to risperidone for treating autistic disorders. BMC Psychiatry 2013;13:196.

185 Nikoo M, Radnia H, Farokhnia M, Mohammadi M-R, Akhondzadeh S: N-acetylcysteine as an adjunctive therapy to risperidone for treatment of irritability in autism: a randomized, double-blind, placebo-controlled clinical trial of efficacy and safety. Clin Neuropharmacol 2015;38:11-17.

186 Wink LK, Adams R, Wang Z, Klaunig JE, Plawecki MH, Posey DJ, et al: A randomized placebo-controlled pilot study of N-acetylcysteine in youth with autism spectrum disorder. Mol Autism 2016;7:26.

187 Dean OM, Gray KM, Villagonzalo K-A, Dodd S, Mohebbi M, Vick T, et al: A randomised, double blind, placebo-controlled trial of a fixed dose of $\mathrm{N}$-acetyl cysteine in children with autistic disorder. Aust NZ J Psychiatry 2017;51:241-249.

188 Li Q, Zhou J-M: The microbiota-gut-brain axis and its potential therapeutic role in autism spectrum disorder. Neuroscience 2016; 324:131-139.

189 Doenyas C: Gut microbiota, inflammation, and probiotics on neural development in autism spectrum disorder. Neuroscience 2018; 374:271-286.

190 Yang Y, Tian J, Yang B: Targeting gut microbiome: a novel and potential therapy for autism. Life Sci 2018;194:111-119.

191 Sandler RH, Finegold SM, Bolte ER, Buchanan CP, Maxwell AP, Väisänen ML, et al: Short-term benefit from oral vancomycin treatment of regressive-onset autism. J Child Neurol 2000;15:429-435.
192 Kałużna-Czaplińska J, Błaszczyk S: The level of arabinitol in autistic children after probiotic therapy. Nutrition 2012;28:124-126.

193 Kang D-W, Adams JB, Gregory AC, Borody T, Chittick L, Fasano A, et al: Microbiota transfer therapy alters gut ecosystem and improves gastrointestinal and autism symptoms: an open-label study. Microbiome 2017;5:10.

194 Pärtty A, Kalliomäki M, Wacklin P, Salminen S, Isolauri E: A possible link between early probiotic intervention and the risk of neuropsychiatric disorders later in childhood: a randomized trial. Pediatr Res 2015; 77:823-828.

195 Seki Y, Kato TA, Monji A, Mizoguchi Y, Horikawa H, Sato-Kasai M, et al: Pretreatment of aripiprazole and minocycline, but not haloperidol, suppresses oligodendrocyte damage from interferon- $\gamma$-stimulated microglia in co-culture model. Schizophr Res 2013;151:20-28.

196 Sobiś J, Rykaczewska-Czerwińska M, Świętochowska E, Gorczyca P: Therapeutic effect of aripiprazole in chronic schizophrenia is accompanied by anti-inflammatory activity. Pharmacol Rep 2015;67:353-359.

197 Leng Y, Chuang D-M: Endogenous alphasynuclein is induced by valproic acid through histone deacetylase inhibition and participates in neuroprotection against glutamate-induced excitotoxicity. J Neurosci 2006;26:7502-7512.

198 Song R, Yu D, Yoon J, Park J: Valproic acid attenuates the expression of pro-inflammatory cytokines lipopolysaccharide-treated canine peripheral blood mononuclear cells (in vitro) and in a canine endotoxemia model (in vivo). Vet Immunol Immunopathol 2015;166:132-137.

199 Suda S, Katsura K, Kanamaru T, Saito M, Katayama Y: Valproic acid attenuates ischemia-reperfusion injury in the rat brain through inhibition of oxidative stress and inflammation. Eur J Pharmacol 2013;707: 26-31.

200 Ximenes JCM, de Oliveira Gonçalves D, Siqueira RMP, Neves KRT, Santos Cerqueira G, Correia AO, et al: Valproic acid: an anticonvulsant drug with potent antinociceptive and anti-inflammatory properties. Naunyn Schmiedebergs Arch Pharmacol 2013; 386:575-587.

201 Chugani DC, Chugani HT, Wiznitzer M, Parikh S, Evans PA, Hansen RL, et al: Efficacy of low-dose buspirone for restricted and repetitive behavior in young children with autism spectrum disorder: a randomized trial. J Pediatr 2016;170:45-53.e1-4.

202 Ghanizadeh A, Ayoobzadehshirazi A: A randomized double-blind placebo-controlled clinical trial of adjuvant buspirone for irritability in autism. Pediatr Neurol 2015;52:7781 
203 McCormick LH: Treatment with buspirone in a patient with autism. Arch Fam Med 1997;6:368-370.

204 Chantiluke K, Barrett N, Giampietro V, Brammer M, Simmons A, Rubia K: Disorder-dissociated effects of fluoxetine on brain function of working memory in attention deficit hyperactivity disorder and autism spectrum disorder. Psychol Med 2015;45: 1195-1205.

205 Hollander E, Soorya L, Chaplin W, Anagnostou E, Taylor BP, Ferretti CJ, et al: A double-blind placebo-controlled trial of fluoxetine for repetitive behaviors and global severity in adult autism spectrum disorders. Am J Psychiatry 2012;169:292-299.

206 Hollander E, Phillips A, Chaplin W, Zagursky K, Novotny S, Wasserman S, et al: A placebo-controlled crossover trial of liquid fluoxetine on repetitive behaviors in childhood and adolescent autism. Neuropsychopharmacology 2005;30:582-589.

207 Alcamí Pertejo M, Peral Guerra M, Gilaberte I: Open study of fluoxetine in children with autism. Actas Esp Psiquiatr 2000;28:353356.

208 Fatemi SH, Realmuto GM, Khan L, Thuras $\mathrm{P}$ : Fluoxetine in treatment of adolescent patients with autism: a longitudinal open trial. J Autism Dev Disord 1998;28:303-307.

209 Owley T, Brune CW, Salt J, Walton L, Guter $\mathrm{S}$, Ayuyao N, et al: A pharmacogenetic study of escitalopram in autism spectrum disorders. Autism Res 2010;3:1-7.

210 Owley T, Walton L, Salt J, Guter SJ, Winnega $M$, Leventhal BL, et al: An open-label trial of escitalopram in pervasive developmental disorders. J Am Acad Child Adolesc Psychiatry 2005;44:343-348.

211 King BH, Hollander E, Sikich L, McCracken JT, Scahill L, Bregman JD, et al: Lack of efficacy of citalopram in children with autism spectrum disorders and high levels of repetitive behavior: citalopram ineffective in children with autism. Arch Gen Psychiatry 2009;66:583-590.

212 Hellings JA, Kelley LA, Gabrielli WF, Kilgore E, Shah P: Sertraline response in adults with mental retardation and autistic disorder. J Clin Psychiatry 1996;57:333-336.

213 McDougle CJ, Brodkin ES, Naylor ST, Carlson DC, Cohen DJ, Price LH: Sertraline in adults with pervasive developmental disorders: a prospective open-label investigation. J Clin Psychopharmacol 1998;18:62-66.

214 Steingard RJ, Zimnitzky B, DeMaso DR, Bauman ML, Bucci JP: Sertraline treatment of transition-associated anxiety and agitation in children with autistic disorder. J Child Adolesc Psychopharmacol 1997;7:915.

215 Posey DJ, Kem DL, Swiezy NB, Sweeten TL, Wiegand RE, McDougle CJ: A pilot study of D-cycloserine in subjects with autistic disorder. Am J Psychiatry 2004;161:2115-2117.
216 Minshawi NF, Wink LK, Shaffer R, Plawecki $\mathrm{MH}$, Posey DJ, Liu $\mathrm{H}$, et al: A randomized, placebo-controlled trial of D-cycloserine for the enhancement of social skills training in autism spectrum disorders. Mol Autism 2016;7:2.

217 Urbano M, Okwara L, Manser P, Hartmann K, Deutsch SI: A trial of D-cycloserine to treat the social deficit in older adolescents and young adults with autism spectrum disorders. J Neuropsychiatry Clin Neurosci 2015;27:133-138.

218 Urbano M, Okwara L, Manser P, Hartmann K, Herndon A, Deutsch SI: A trial of D-cycloserine to treat stereotypies in older adolescents and young adults with autism spectrum disorder. Clin Neuropharmacol 2014; 37:69-72.

219 King BH, Wright DM, Handen BL, Sikich L, Zimmerman AW, McMahon W, et al: Double-blind, placebo-controlled study of amantadine hydrochloride in the treatment of children with autistic disorder. J Am Acad Child Adolesc Psychiatry 2001;40:658-665.

220 Owley T, Salt J, Guter S, Grieve A, Walton L, Ayuyao N, et al: A prospective, open-label trial of memantine in the treatment of cognitive, behavioral, and memory dysfunction in pervasive developmental disorders. J Child Adolesc Psychopharmacol 2006; 16:517524.

221 Chez MG, Burton Q, Dowling T, Chang M, Khanna P, Kramer C: Memantine as adjunctive therapy in children diagnosed with autistic spectrum disorders: an observation of initial clinical response and maintenance tolerability. J Child Neurol 2007;22:574579.

222 Joshi G, Wozniak J, Faraone SV, Fried R, Chan J, Furtak S, et al: A prospective openlabel trial of memantine hydrochloride for the treatment of social deficits in intellectually capable adults with autism spectrum disorder. J Clin Psychopharmacol 2016;36: 262-271.

223 Williams PG, Allard A, Sears L, Dalrymple N, Bloom AS: Brief report: case reports on naltrexone use in children with autism: controlled observations regarding benefits and practical issues of medication management. J Autism Dev Disord 2001;31:103-108.

224 Willemsen-Swinkels SH, Buitelaar JK, van Berckelaer-Onnes IA, van Engeland H: Brief report: six months continuation treatment in naltrexone-responsive children with autism: an open-label case-control design. J Autism Dev Disord 1999;29:167-169.

225 Campbell M, Anderson LT, Small AM, Adams P, Gonzalez NM, Ernst M: Naltrexone in autistic children: behavioral symptoms and attentional learning. J Am Acad Child Adolesc Psychiatry 1993;32:1283-1291.

226 Zingarelli G, Ellman G, Hom A, Wymore M, Heidorn S, Chicz-DeMet A: Clinical effects of naltrexone on autistic behavior. Am J Ment Retard 1992;97:57-63.
227 Leboyer M, Bouvard MP, Launay JM, Tabuteau F, Waller D, Dugas M, et al: Brief report: a double-blind study of naltrexone in infantile autism. J Autism Dev Disord 1992;22: 309-319.

228 Knabe R, Schulz P, Richard J: Initial aggravation of self-injurious behavior in autistic patients receiving naltrexone treatment. J Autism Dev Disord 1990;20:591-593.

229 Walters AS, Barrett RP, Feinstein C, Mercurio $\mathrm{A}$, Hole WT: A case report of naltrexone treatment of self-injury and social withdrawal in autism. J Autism Dev Disord 1990; 20:169-176.

230 Campbell M, Anderson LT, Small AM, Locascio JJ, Lynch NS, Choroco MC: Naltrexone in autistic children: a double-blind and placebo-controlled study. Psychopharmacol Bull 1990;26:130-135.

231 Barrett RP, Feinstein C, Hole WT: Effects of naloxone and naltrexone on self-injury: a double-blind, placebo-controlled analysis. Am J Ment Retard 1989;93:644-651.

232 Feldman HM, Kolmen BK, Gonzaga AM: Naltrexone and communication skills in young children with autism. J Am Acad Child Adolesc Psychiatry 1999;38:587-593.

233 Kolmen BK, Feldman HM, Handen BL, Janosky JE: Naltrexone in young autistic children: replication study and learning measures. J Am Acad Child Adolesc Psychiatry 1997;36:1570-1578.

234 Willemsen-Swinkels SH, Buitelaar JK, van Engeland $\mathrm{H}$ : The effects of chronic naltrexone treatment in young autistic children: a double-blind placebo-controlled crossover study. Biol Psychiatry 1996;39:1023-1031.

235 Willemsen-Swinkels SH, Buitelaar JK, Weijnen FG, van Engeland H: Placebo-controlled acute dosage naltrexone study in young autistic children. Psychiatry Res 1995 58:203-215.

236 Bouvard MP, Leboyer M, Launay JM, Recasens C, Plumet MH, Waller-Perotte D, et al: Low-dose naltrexone effects on plasma chemistries and clinical symptoms in autism: a double-blind, placebo-controlled study. Psychiatry Res 1995;58:191-201.

237 Willemsen-Swinkels SH, Buitelaar JK, Nijhof GJ, van Engeland H: Failure of naltrexone hydrochloride to reduce self-injurious and autistic behavior in mentally retarded adults. Double-blind placebo-controlled studies. Arch Gen Psychiatry 1995;52:766773.

238 Kolmen BK, Feldman HM, Handen BL, Janosky JE: Naltrexone in young autistic children: a double-blind, placebo-controlled crossover study. J Am Acad Child Adolesc Psychiatry 1995;34:223-231.

239 Gonzalez NM, Campbell M, Small AM, Shay J, Bluhm LD, Adams PB, et al: Naltrexone plasma levels, clinical response and effect on weight in autistic children. Psychopharmacol Bull 1994;30:203-208. 
240 Scifo R, Cioni M, Nicolosi A, Batticane N, Tirolo C, Testa N, et al: Opioid-immune interactions in autism: behavioural and immunological assessment during a double-blind treatment with naltrexone. Ann Ist Super Sanita 1996;32:351-359.

241 Al-Ayadhi LY, Halepoto DM, Al-Dress AM, Mitwali Y, Zainah R: Behavioral benefits of camel milk in subjects with autism spectrum disorder. J Coll Physicians Surg Pak 2015;25: 819-823.

242 Bashir S, Al-Ayadhi LY: Effect of camel milk on thymus and activation-regulated chemokine in autistic children: double-blind study. Pediatr Res 2014;75:559-563.

$243 \mathrm{Hu}$ Y, Ehli EA, Boomsma DI: MicroRNAs as biomarkers for psychiatric disorders with a focus on autism spectrum disorder: current progress in genetic association studies, expression profiling, and translational research. Autism Res 2017;10:1184-1203.

244 Fregeac J, Colleaux L, Nguyen LS: The emerging roles of microRNAs in autism spectrum disorders. Neurosci Biobehav Rev 2016;71:729-738.
245 Inga Jácome MC, Morales Chacòn LM, Vera Cuesta H, Maragoto Rizo C, Whilby Santiesteban M, Ramos Hernandez L, et al: Peripheral inflammatory markers contributing to comorbidities in autism. Behav Sci 2016; 6:pii: E29.

246 Ahmad SF, Nadeem A, Ansari MA, Bakheet SA, Attia SM, Zoheir KMA, et al: Imbalance between the anti- and pro-inflammatory milieu in blood leukocytes of autistic children. Mol Immunol 2017;82:57-65.

247 Singh VK: Phenotypic expression of autoimmune autistic disorder (AAD): a major subset of autism. Ann Clin Psychiatry 2009;21: 148-161.

248 Kim J-W, Seung H, Kwon KJ, Ko MJ, Lee EJ, Oh HA, et al: Subchronic treatment of donepezil rescues impaired social, hyperactive, and stereotypic behavior in valproic acidinduced animal model of autism. PLoS One 2014;9:e104927.

249 Karvat G, Kimchi T: Acetylcholine elevation relieves cognitive rigidity and social deficiency in a mouse model of autism. Neuropsychopharmacology 2014;39:831-840.

250 Bakheet SA, Alzahrani MZ, Ansari MA, Nadeem A, Zoheir KMA, Attia SM, et al: Resveratrol ameliorates dysregulation of Th1, Th2, Th17, and T regulatory cell-related transcription factor signaling in a BTBR $\mathrm{T}+\mathrm{tf} / \mathrm{J}$ mouse model of autism. Mol Neurobiol 2017;54:5201-5212.
251 Bakheet SA, Alzahrani MZ, Nadeem A, Ansari MA, Zoheir KMA, Attia SM, et al: Resveratrol treatment attenuates chemokine receptor expression in the BTBR $\mathrm{T}+\mathrm{tf} / \mathrm{J}$ mouse model of autism. Mol Cell Neurosci 2016;77:1-10.

252 Bhandari R, Kuhad A: Resveratrol suppresses neuroinflammation in the experimental paradigm of autism spectrum disorders. Neurochem Int 2017;103:8-23.

253 Bambini-Junior V, Zanatta G, Della Flora Nunes G, Mueller de Melo G, Michels M, Fontes-Dutra M, et al: Resveratrol prevents social deficits in animal model of autism induced by valproic acid. Neurosci Lett 2014; 583:176-181.

254 Wu H, Wang X, Gao J, Liang S, Hao Y, Sun C, et al: Fingolimod (FTY720) attenuates social deficits, learning and memory impairments, neuronal loss and neuroinflammation in the rat model of autism. Life Sci 2017; 173:43-54.

255 Hirsch MM, Deckmann I, Fontes-Dutra M, Bauer-Negrini G, Della-Flora Nunes G, Nunes W, et al: Behavioral alterations in autism model induced by valproic acid and translational analysis of circulating microRNA. Food Chem Toxicol 2018;115:336343. 